\title{
Brighter prospects? Assessing the franchise advantage using census data
}

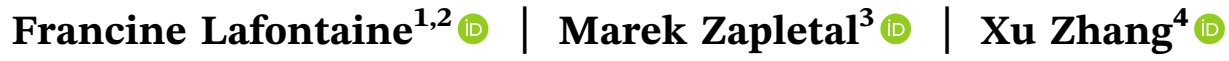

${ }^{1}$ Ross School of Business, University of Michigan, Ann Arbor, Michigan, USA

${ }^{2}$ Centre for Economic Policy Research, London, UK

${ }^{3}$ The Brattle Group, Boston,

Massachusetts

${ }^{4}$ London Business School, London, UK

\section{Correspondence}

Francine Lafontaine, Ross School of Business, University of Michigan, Ann Arbor, MI 48109.

Email: laf@umich.edu

\begin{abstract}
This paper uses Census microdata to examine how starting a business as a franchise rather than an independent business affects its survival and growth prospects. We assess factors that influence the decision to become a franchisee and use various empirical approaches to correct for selection bias in our performance analyses. We find that franchised businesses on average exhibit higher survival rates than independent businesses; but importantly, the difference is small compared with claims in the trade press. The effect is also short lived: conditional on surviving a year or two, we no longer find survival (or growth) differences. We then explore two potential sources for this small survival advantage, namely franchisors' screening process and the benefits arising from the brand and business know-how provided by franchisors. We find evidence that both of the sources contribute to the franchising advantage.
\end{abstract}

\section{K E Y W O R D S}

Business growth, business survival, entrepreneurship, franchising, independent business, know-how, retail, screening, services, Survey of Business Owners (SBO)

\section{1 | INTRODUCTION}

Franchising is an important form of business organization in many retail and service industries, which themselves constitute a large and growing segment of the US economy. According to the US Census Bureau, there were 453,326 establishments of franchised chains in 2007, contributing $\$ 154$ billion in payroll for their 7.9 million employees. ${ }^{1}$ Given its importance in the US economy, it is perhaps surprising that research on franchising decisions, and its effect on business performance, remains scarce. The goal of this paper is to investigate specifically whether franchised businesses' survival and growth prospects compare favorably with those of independent businesses.

Whether franchised businesses are more likely to be successful, that is, whether they are more likely to survive longer, has been of much interest to industry participants and scholars. One regularly finds claims in the trade press suggesting that starting a franchise is a much safer way of going into business. The empirical evidence on this topic, however, has been mixed. ${ }^{2}$ Bates (1995a) and (1995b), for example, documented that in the late 1980s, the failure rate of franchised businesses was somewhat greater than that of the independent businesses, and much greater than that suggested by industry insiders and the trade press. ${ }^{3}$ In summarizing the literature on this topic, Blair and Lafontaine (2005) state:

[...] substantial business risks exist for individuals who choose to invest in a franchise. In fact, franchising is no safer on average than independent business ownership, and in some cases is actually riskier. [...] Of course, business failure is a fact of life. Our point is that this is just as true for franchisors and franchisees as it is for other players in the economy. We see this as no cause for alarm, but as a fact that should be more widely 
known and recognized in the franchise community. Ultimately, a false sense of security can only lead to hardship and disappointment.

In theory, it is indeed unclear whether franchised or independent businesses should have a survival advantage. On the one hand, starting a business as a franchise should be less risky than launching an independent business because franchisees benefit from their franchisor's brand name awareness and know-how and may realize cost savings from more efficient supply chains and bulk purchasing. That franchised establishments have become a ubiquitous part of modern life today suggests that franchising is often an efficient mode of business entry and operation. Independent business owners, however, do not have to pay franchise fees or ongoing royalties on revenues, and they retain complete autonomy, allowing them to adapt as needed to their local market and changing market conditions. These differences allow for the possibility of superior performance by nonfranchised businesses. The coexistence of both types of businesses in the marketplace suggests that neither form of business ownership clearly dominates the other.

In this paper, we use Census data to assess whether the survival and growth prospects of franchised businesses are more promising than those of independent businesses. Of course, this analysis requires caution because the franchising decision is not random, and the factors that affect the franchising decision may also affect survival directly. Thus, one must control for "selection into franchising" when examining whether franchising has a direct effect on survival (see, e.g., Kosová, Lafontaine, and Perrigot (2013) on this issue). Williams (1999), Kaufmann (1999), and Mazzeo (2004), for example, show that characteristics of the business owners, such as education, age, and managerial experience, increase the likelihood of entering into a franchise relationship relative to independent business startup. Our findings on the factors that affect the probability of starting a franchise relative to an independent business are in line with theirs.

We also contribute to the broad literature on the extent of, and determinants of, the survival and growth prospects of business startups. ${ }^{4}$ Factors that have been identified in this literature can be grouped into three broad categories: characteristics of business owners, including race and gender, and measures of their human capital, such as education and prior business experience (Bates, 1990; Boden \& Nucci, 2000; Cooper, Gimeno-Gascon, \& Woo, 1994; Cressy, 1996; Evans \& Leighton, 1989; Fairlie \& Robb, 2008; Kalleberg \& Leicht, 1991; Kalnins \& Mayer, 2004; Lafontaine and Shaw, 2016; Lazear, 2004; Millán, Congregado, \& Román, 2010; Pfeiffer \& Reize, 2000); the amount of capital and the sources of financing that a business owner is able to access to start their business (e.g., Bates, 1990, Carpenter \& Petersen, 2002, Cooper et al., 1994, Cressy, 1996, Fan et al., 2017, Holtz-Eakin, Joulfaian, \& Rosen, 1994, Hurst \& Lusardi, 2004, Kamshad, 1994, Kerr, Kerr, \& Nanda, 2015, Schäfer \& Talavera, 2007); and finally, the macroeconomic conditions faced by the business. The latter includes factors affecting the industry within which the new business operates, the local business environment, and the regional or national level of economic activity (e.g., Agarwal \& Audretsch, 2001; Audretsch \& Mahmood, 1995; Audretsch, Houweling, \& Thurik, 2000; Boden \& Nucci, 2000; Fritsch, Brixy, \& Falck, 2006; Haapanen \& Tervo, 2009; Pfeiffer \& Reize, 2000; Tveterås \& Eide, 2000; Wagner, 1994). A number of these factors, however, arise from decisions made by business owners. Examples include the form of financing, the timing of entry, the location and choice of business activities, and the skills that the entrepreneur chooses to acquire (see, e.g., Cressy 1996, Kalnins \& Lafontaine, 2013, Lazear, 2004, Pfeiffer \& Reize, 2000). The issue of selection mentioned above applies here as well and is addressed in some of this literature. For our purposes, however, the main point is to recognize that these factors need to be controlled for in the analyses of the effect of the franchising decision on both business survival and growth.

Our data are from the US Census Bureau's Survey of Business Owners (SBO) and Longitudinal Business Database (LBD). The SBO provides information on selected characteristics of businesses and business owners. The LBD includes information on all businesses, including the timing of entry and their yearly employment. We rely on the LBD to determine survival status for the first few years in business and measure business growth over this period. The industries covered in this study are the retail trade sector (North American Industry Classification System [NAICS] 44-45), the accommodation and food services sector (NAICS 72), and other services sector (NAICS 81). ${ }^{5}$ These sectors together accounted for more than $77 \%$ of franchised businesses according to the 2007 Census (Kosová \& Lafontaine, 2012).

We find that in simple mean comparisons, the 1-year survival rate of new single-establishment franchised businesses is about 6 percentage points higher than that of independent businesses. For the 2-year survival rate, this difference is 7 percentage points. These are much smaller differences than those mentioned in much of the trade press. ${ }^{6}$ This is partly because the average survival rates of both kinds of businesses are higher than one might expect based on the trade press-at around $90 \%$ for 1 year and $80 \%$ for 2 years-leaving little room for a higher survival rate for franchises. Controlling for factors that may lead an individual to pursue a franchise rather than open an independent business reduces the difference in survival rate slightly, to about 5 percentage points for the 1-year survival rate, and 6 percentage points for the 2-year survival rate. We use Rosenbaum sensitivity tests as well as an instrumental variable (IV) and a 


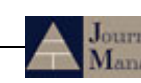

control function (CF) approach to assess the robustness of these results. We find some evidence that franchised businesses have a better survival rate and faster growth than independent businesses in the short term, though our most demanding identification methods imply differences that are not statistically different from zero. Focusing on our less demanding identification strategies, we find that franchised businesses benefit from greater odds of surviving in their first year, an advantage that manifests itself again in a greater probability of making it also to years two and three. But conditional on surviving for a year, the differences in survival or growth basically disappear even under our less demanding methodologies. The absence of further survival or growth advantage conditional on surviving the first year suggests that whatever the franchise model provides to business owners helps them make it through the first year, but independent businesses that also survive their first year are basically on an equal footing from that point on.

This paper is organized as follows. In Section 2, we briefly describe why new franchised businesses of new owners could perhaps perform better than new independent businesses of new owners. In Section 3, we describe the data. In Section 4, we present our empirical approach and interpret results. We conclude this paper in Section 5.

\section{2 | POTENTIAL SOURCES OF FRANCHISE ADVANTAGE}

Lists of potential advantages of franchising found in textbooks and the trade press typically include brand recognition, which enhances demand locally, and the transfer of business know-how by franchisors, which encompasses welldeveloped supply relationships and operations manuals that can lead to cost advantages and more efficient operations in franchised businesses. ${ }^{7}$ Franchisors, however, charge ongoing fees to their franchisees, fees that might capture most, if not all, of the value created by the business-enhancing benefits associated with franchising. In the end, whether franchisor-provided services and business-enhancing knowledge result in a long-term franchise advantage given these fees is an empirical question.

There is another potential source of franchise advantage, however, one that arises from the fact that franchisors screen applicants. Starting an independent business is essentially an individual business owner's decision. Starting a franchised business is a joint decision: the franchisee needs to determine that they want to operate a particular franchise and the franchisor must decide who they will allow to become a franchisee. Franchisors often impose prequalifying conditions on candidates and potentially on location and other aspects of the business. ${ }^{8}$ This screening could yield a temporary survival benefit for franchised businesses if independent businesses are more easily started and then sorted out by market forces instead. In the longer term, however, the fees charged by franchisors also could extract most of the benefits arising from the franchisors' selection of franchisees and business characteristics. Thus, whether the franchise advantage that might arise from the screening/selection imposed by franchisors continues beyond the trial and error period that all businesses are subjected to in their first few years is also an empirical issue.

Some of the empirical literature (e.g., Stanworth et al., 1998) suggests that there may not be any advantage from franchising. Similarly, recent reports from the Small Business Administration (SBA) suggest that franchise failure rates can be quite high and comparable generally with those of independent businesses. For example, franchise-brandspecific data published on the Blue Maumau website show high rates of failure to pay back SBA-backed loans issued to franchisees. ${ }^{9}$ On average, across 580 brands included in the data, the failure rate is $24.5 \%$ for loans issued at some point in the previous 10 years. Data indicate the same failure rate is $19.5 \%$, for example, for all (franchised or not) Full-Service Restaurants, and $20.7 \%$ for all Limited-Service Restaurants. ${ }^{10}$ It is therefore conceivable that franchised businesses may not outperform comparable independent businesses. In the end, as mentioned above and in Blair and Lafontaine (2005), the continued coexistence of both franchised and independent businesses in the sectors where business-format franchising occurs suggests that independent businesses are able to compete effectively with franchised businesses.

\section{DATA}

We rely on several sources of data from the US Census Bureau to construct our data set of new businesses. First, we use the SBO, a confidential US Census Bureau survey conducted for the first time in 2002, which includes information about whether a business is franchised or independent. ${ }^{11}$ The Census surveyed 2.2 million businesses (and their owners) in 2002 and 2007, and 1.75 million businesses in 2012, yielding response rates between $60 \%$ and $75 \%$ in the three SBO surveys. 
The SBO universe includes all nonfarm businesses with annual receipts of at least $\$ 1,000$ that filed Internal Revenue Service tax forms as individual proprietorships, partnerships, or corporations. The SBO collects information on the characteristics of the business (e.g., sector of operation, legal form of organization, and franchise status) and the business owner (e.g., gender, race, age, and education). These variables enable us to examine the effect of owner characteristics on business performance directly, and control for differences between franchised and independent businesses and differences in the characteristics of their owners as well. As described in Section 4, because many of the characteristics that affect the decision to start a franchised or an independent business are also expected to affect performance, our estimates of the effect of franchising on survival or growth would likely be biased upward if we did not control for these. In other words, our estimates could suggest that survival or growth is positively affected by franchising when in reality, the survival or growth differential may be attributable to differences in the characteristics of the businesses or their owners.

The LBD is another confidential Census Bureau database. It provides annual information on all private sector employer establishments in the United States, that is, all establishments with a payroll. ${ }^{12}$ Merging the LBD with the SBO enables us to measure the survival of employer businesses surveyed in the SBO (the match rate is high, around $98 \%$ for each of the three surveys, i.e., SBO 2002, 2007, and 2012).

To limit effects arising from differences in survival rates documented for businesses started by owners with prior experience in franchising (Bates, 1998) or in business more generally (Kalnins \& Lafontaine, 2013; Lafontaine \& Shaw, 2016), we restrict our analyses to establishments of owners with no other business. ${ }^{13}$ In addition, to avoid survivorship bias in the data, namely cases where, to appear in the surveys, firms must have survived up to the survey year, we focus on businesses started in the SBO year, namely 2002, 2007, or $2012 .{ }^{14}$ We further limit our analyses to privately owned businesses whose main owner had at least a 50\% stake. This restriction ensures that the business owner whose characteristics we control for indeed can influence the business and its success. Our interest is in understanding for-profit enterprises, so we eliminate nonprofit establishments and businesses owned by an estate, a trust, or members of a club. Finally, our goal being to assess the success of franchised relative to independent businesses, we restrict our sample to those businesses operating in sectors where franchising is a real option. In particular, we include new businesses in the retail trade sector (NAICS 44-45), in the accommodation and food services sector (NAICS 72), and in other service sectors (NAICS 81), which together account for about 77\% of franchised businesses in 2007 according to the Census Bureau. ${ }^{15}$ Within these broad sectors, we further limit our analyses to four-digit NAICS industries in which at least 3\% of businesses in our SBO data are franchised. Finally, we exclude automobile dealers and gasoline stations as state laws govern the franchise decisions in these sectors (in all states for automobile dealerships, and some states for gasoline stations). Our final list of four-digit NAICS industries is shown in Table 1. As one might expect, limited-service eating places and traveler accommodations are the two sectors with the highest franchising rates.

Our final sample consists of 5,200, 1,700, and 2,100 single-establishment businesses from the 2002, 2007, and 2012 SBO surveys respectively. ${ }^{16}$ Relative to the $10.5 \%$ of businesses identified as franchised in the 2007 Economic Census, we find that $13.0 \%$ of businesses in our final combined sample are franchised. This somewhat higher fraction is, of course, sensible given our focus on franchising-relevant sectors.

For each business in our data, we generate a series of binary variables that indicate whether it is still operating $t$ years after it was started. We run separate analyses for each survival duration up to 3 years after the business startup year. It is important to note that the LBD records a business sold to another owner as an exit and entry of a new business. According to the trade press, small business owners who sell their businesses often receive less than predicted future cash flows would warrant. As a result, such business sales may well represent a type of failure, in which case the Census's coding correctly captures the event of interest. Of course, in reality, not all business sales are business failures. However, considering that we focus on only a few years post starting the business, we expect most owners of the new businesses to sell a successful business only if they face a major change of plans. Given this, we expect the measurement error arising from this issue to be small in our data. Moreover, how this measurement error might affect our analyses and results depends on whether the buying and selling of new franchises for reasons unrelated to failure (e.g., for reasons having to do with owners wanting to pursue other opportunities), is systematically different from this tendency for new owners of independent businesses. We have no reason to expect such a difference. Thus, counting all sales as failures may mean that our descriptive statistics somewhat underestimate the true survival rates of both types of businesses, but we believe that the difference in survival rates between the two types of businesses is likely to be correctly estimated, and the coefficient on the franchise indicator variable in our regressions below to be unbiased. ${ }^{17}$ 
TABLE 1 The proportion of franchised businesses across sectors

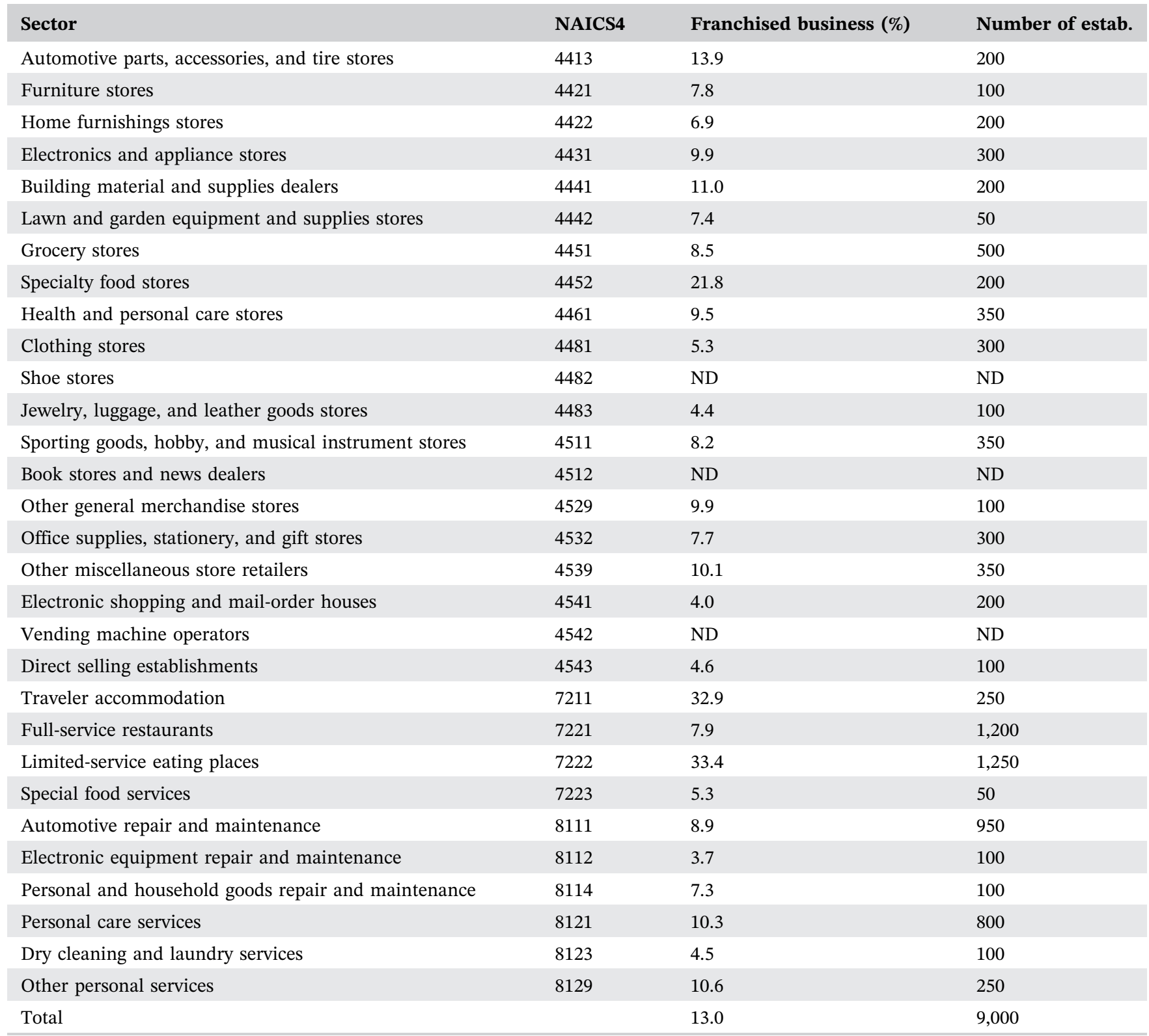

Note. To satisfy US Census Bureau disclosure procedures, we report the franchise proportion among new businesses in our combined 2002, 2007, and 2012 sample and suppress information for a few sectors that fail to meet the disclosure requirements, denoted as ND. All counts are rounded to satisfy the disclosure requirements - if $N$ is less than 100, round to the nearest 10; if $N$ is between 100 and 999 , round to the nearest 50 ; if $N$ is between 1,000 and 9,999 , round to the nearest 100 . We use these rounding rules throughout the paper, unless otherwise noted.

Table 2 reports descriptive statistics for all variables, by franchise status, in our combined 2002, 2007, and 2012 SBO sample. ${ }^{18}$ Our main dependent variables, namely the rates of business survival and employment growth, are higher for franchised startups, suggesting a positive franchise advantage. The 1-year survival rate is $97 \%$ for franchised, and $91 \%$ for independently owned businesses, for a 6 percentage point franchise advantage. The 2 -year survival rates of $88 \%$ and $81 \%$ yield a 7 percentage point advantage, whereas the 3-year survival advantage of franchised over independent businesses is greatest in these data, at 9 percentage points. We use employment data to measure business growth. We find that in the first year, both franchised and independent businesses have small employment numbers. ${ }^{19}$ In the second year, the employment numbers become larger but remain relatively flat from that time onward.

Comparing business owner characteristics across new franchised and new independent businesses, we observe evidence of "self-selection into franchising." In all, $67 \%$ of business owners are male in our data, but an even greater percentage of franchised businesses is started by men. Whether this is due to a greater number of men approaching franchisors or franchisors selecting male candidates cannot be ascertained from these data. Looking at the age and 
TABLE 2 Summary statistics

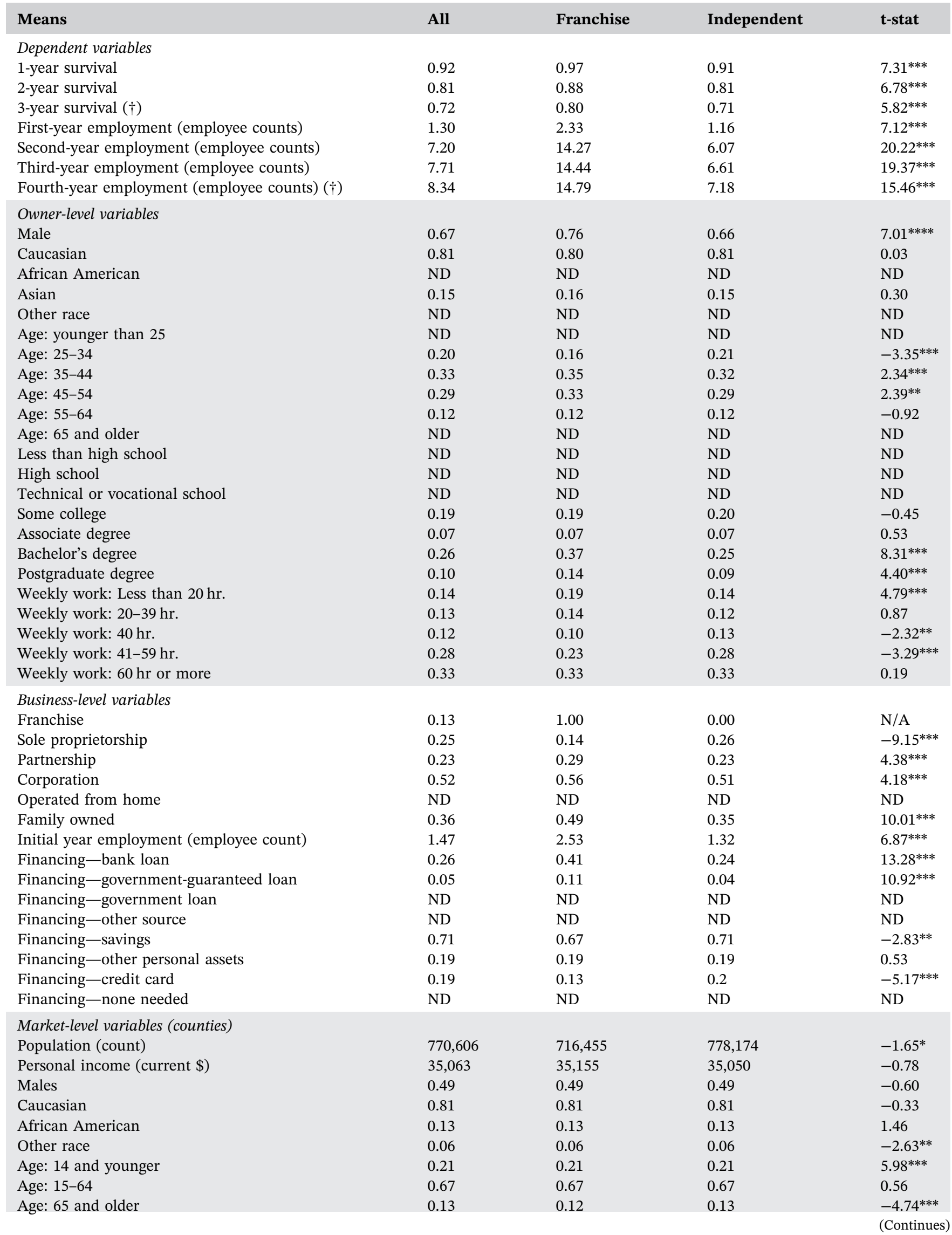


TABLE 2 (Continued)

\begin{tabular}{llllr} 
Means & All & Franchise & Independent & t-stat \\
At least high school degree & 0.87 & 0.87 & 0.86 & 0.07 \\
Unemployed & 0.07 & 0.07 & 1,258 & $-4.05^{* * * *}$ \\
Geographic area (square miles) & 1,249 & 1,213 & 0.68 & -1.10 \\
MSA central county & 0.68 & 0.72 & 0.08 & $0.01^{* *}$ \\
MSA outside county & 0.08 & 0.08 & 0.25 \\
Non-MSA county & 0.24 & 0.20 & $-3.45^{* * *}$ \\
Observations & 9,000 & 1,150 & 7,850 & \\
\hline
\end{tabular}

Note. The last column reports two-sided equal-variance $t$ tests between franchised and independent businesses in the combined 2002, 2007, and 2012 SBO sample. $\dagger$ denotes using only the combined 2002 and 2007 SBO sample (2015 LBD is not available to calculate some of the summary statistics for the 2012 SBO subsample). ${ }^{* * *}, * *$, and * indicate statistical significance at the $1 \%, 5 \%$, and $10 \%$ levels, respectively. Cells that fail the disclosure criteria are denoted as ND. Results for variables unavailable in at least one of the SBO surveys are not included in the table. They are "Financing-home equity loan," "Financing-loan from family/friends," "Financing—other sources of capital," "Financing_grants," "Financing_venture capital," and "Financing—do not know." LBD: Longitudinal Business Database; SBO: Survey of Business Owners; MSA: Metropolitan Statistical Area

education distributions, franchise business owners tend to be older and more educated when starting their business. All these data patterns may be due to the types of individuals who want to become franchisees or result from the selection process of franchisors.

When asked to describe how much they work, on average, independent business owners report working for longer hours than franchise business owners. Franchised businesses are also more likely to be organized as partnership or corporations rather than sole proprietorships and more likely to be family owned. They also tend to be somewhat larger in terms of initial employment size, and more likely to rely on bank loans and government-guaranteed loans, but less likely to rely on savings and credit cards, as sources of financing. In terms of location, franchised businesses are more likely than independent businesses to be found in central Metropolitan Statistical Area (MSA) counties.

To get a better understanding of the survival rates of retail and service businesses across industries and across US states, we report the average 1-, 2-, and 3-year survival rates across four-digit NAICS industries in Table 3. Ideally, we would provide these statistics on the sample of businesses we analyze below. However, because of the US Census Bureau disclosure criteria, we cannot include this information. As a compromise, we report summary statistics on the survival prospects for a larger sample, namely all the businesses started during the 2003 to 2007 period per the LBD. This approach has the advantage of providing information on what is a more representative sample of businesses, compared with our sample of businesses that are single-establishment, majority owned by an individual owner, forprofit, nonseasonal, and so on.

The table shows that the 3-year survival rates range from $54 \%$ to $78 \%$, with businesses in the direct selling sector having the lowest survival rate and shoe stores having the highest survival rate. On average, 1-, 2-, and 3-year survival rates for the new establishments in the LBD are lower, at $87 \%, 73 \%$, and $63 \%$, respectively, than the corresponding $92 \%$, $81 \%$, and $72 \%$ survival rates in our data. ${ }^{20}$

Finally, Figure 1 presents a US heat map of state-level business 3-year survival rates, stated as fractions, for the larger LBD sample. It shows that the midwest and northeast regions have relatively higher business survival rates, whereas the southeast exhibits relatively low survival rates. Most important for our purposes, Figure 1 confirms that we should control for state fixed effects in our survival analyses below.

\section{4 | ECONOMETRIC SPECIFICATION AND RESULTS}

\section{1 $\quad$ The franchising decision}

In this section, we focus on the factors that affect the franchising decision, using the following general specification:

$$
\text { Franchise }_{i k c s \tau}=f\left(X_{i k c s}, M_{i c}, \eta_{k}, \delta_{s}, \gamma_{\tau}, \varepsilon_{i k c s}\right) \text {, }
$$

where Franchise $_{i k c s t}$ is equal to 1 if the business is franchised, and 0 otherwise, and subscript $i$ identifies the business, started in SBO survey year $\tau, k$ indexes the four-digit NAICS code for the business, $c$ denotes the county, and $s$ denotes 
TABLE 3 Survival rates across sectors

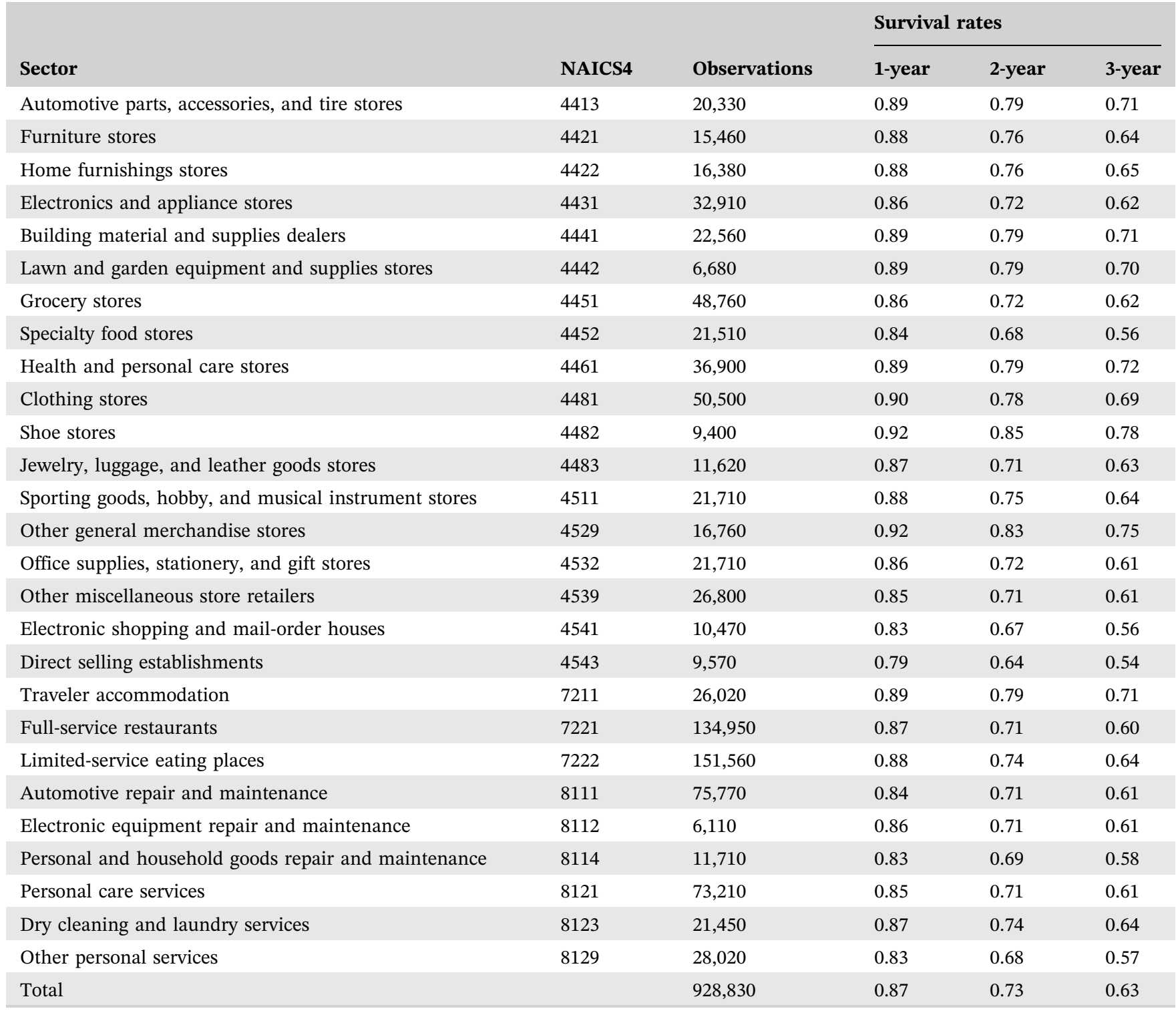

Note. Survival rates are reported as fractions. All counts are rounded to tens to satisfy US Census Bureau disclosure requirements. The data used in this table relates to all establishments started in any year between 2003 and 2007 (including 2003 and 2007), which is a much larger set of establishments than the one we focus on in our analyses below. Such decision is made to report broad patterns in survival rates, but of course this implies that the above data do not focus on the single-establishment, single owner, nonseasonal, nontemporary, etc., businesses. The above information is, thus, only suggestive for our sample.

the state. The $X$ vector includes owner and business characteristics. Specifically, we include indicator variables for owner age, gender, race, and education, and sources of financing. As Mazzeo (2004) finds that heterogeneity in the economic environment is correlated with the franchising decision, we also include market-level (county) characteristics for the year in which the business was started, such as the mean personal income per capita and demographic characteristics of the county's population, denoted by $M_{\mathrm{ic}}$. To account for various common but unobserved constant factors associated with each SBO survey year, and those that characterize various NAICS industries and US states, we include a set of SBO survey year, industry (four-digit NAICS) and state fixed effects (FE), denoted by $\gamma_{\tau}, \eta_{k}$, and $\delta_{s}$, respectively. Note that we cannot include franchisor characteristics to capture the potential effect of the franchisor's selection process in our regressions because we do not know the relevant set of franchisors considered by the owner of the business (irrespective of whether the business is ultimately franchised or independently owned). However, our various fixed effects should capture some of the variation in the characteristics of the relevant set of franchisors at the SBO survey year, industry and state level, respectively. Any remaining effect of these characteristics beyond these fixed effects will be captured by the error term in the above equation. ${ }^{21}$ 


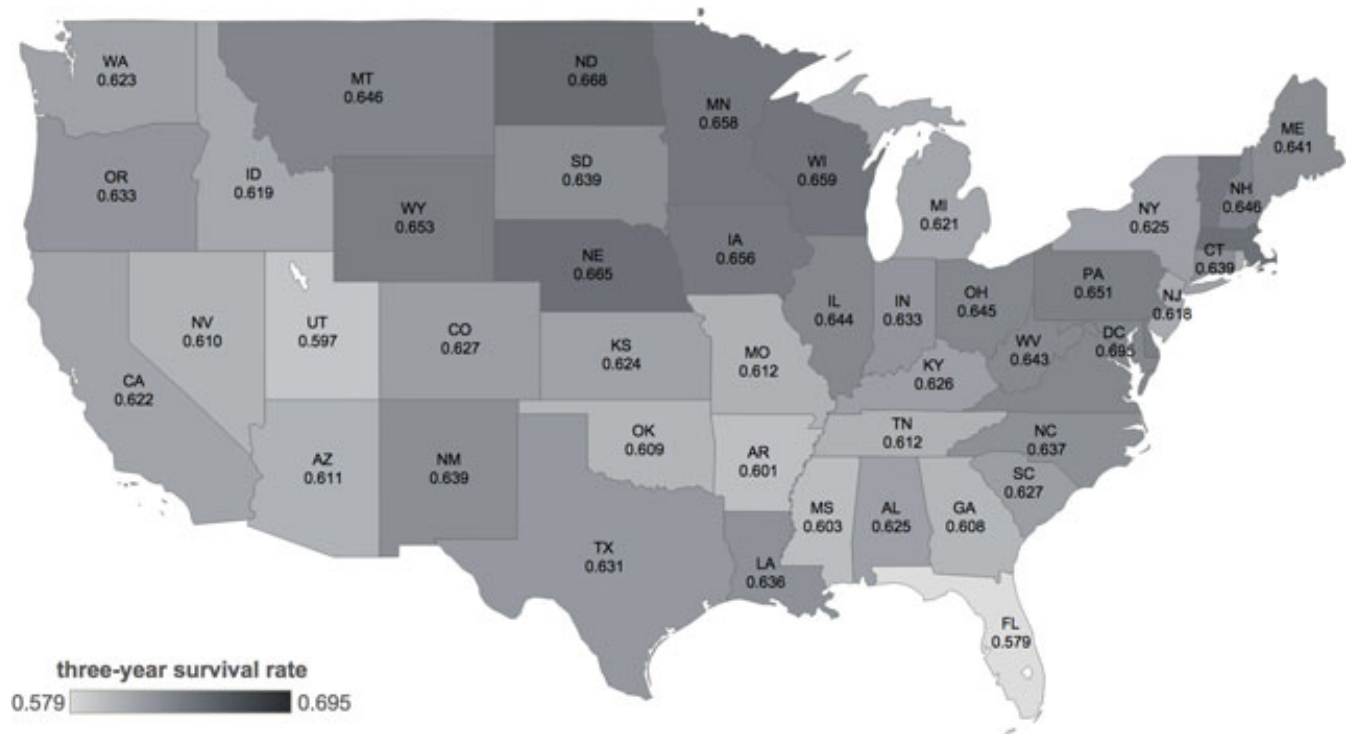

F I G U RE 1 Three-year survival rates across US states. Note: The data in this figure include all establishments started in any year between 2003 and 2007 (including 2003 and 2007), which is a much larger set of establishments than the one we analyzed. We do this to have a larger data set to calculate survival rates, but of course this means that the above data are not descriptive of the single-establishment, single owner, nonseasonal, nontemporary, and so on, businesses that we focus on. Indeed, a comparison of the survival rates shows that the businesses in our data have greater rates of survival than do the new businesses in the broader LBD shown here. LBD: Longitudinal Business Database

To assess the robustness of our results to functional form assumptions, we estimated the above franchise decision regression under a linear probability model, a probit model, and a logit model on each individual-year SBO sample as well as the combined 2002, 2007, and 2012 SBO sample. We find that the marginal effects at the mean estimated from the probit and logit models are similar in magnitude and statistical significance levels to those we obtain from the linear probability model. Moreover, the results are also similar across SBO survey years. ${ }^{22}$ Consequently, in what follows, we present and discuss only results from the linear probability model for the combined sample with survey-year fixed effects.

Results, in Table 4, first confirm that the characteristics of owners do affect the decision to start a franchised rather than an independent business. Consistent with the descriptive statistics in Table 2, even after controlling for other factors, we find that men are about $4 \%$ more likely than women, and Asians are $2 \%$ less likely than Caucasians (the default category), to start a franchised business. Similarly, education matters. Entrepreneurs with higher education levels are more likely to start a franchised business: individuals with a bachelor degree are about $8 \%$, and those with a postgraduate degree are about $7 \%$, more likely than those with a high school degree or less to start a franchised business.

In Columns (2) and (3), we include variables that capture the sources of financing used, which could be correlated with age and education and gender, and thus could bias our estimates of effects for these variables if excluded from the regressions. Consistent with this possibility, we find that the magnitudes of the effects of demographic variables become smaller after we control for sources of financing. We also find that reliance on bank loans and government-guaranteed loans ${ }^{23}$ is highly correlated with starting a franchised business, whereas credit card usage and statements of "no capital needed" are negatively correlated with starting a franchised business. Of course, if banks and government agencies believe that a franchised business is a safer way for entrepreneurs to start a business, or if franchising makes it easier for business owners to prepare their business plans and provide information to financial institutions, then franchised business owners are more likely to obtain a government-guaranteed loan or a loan from a financial institution, and thus less likely to have to rely on credit cards or owner's assets. In other words, the causality here easily can run the other way.

In Column (3), we add work intensity, the business's legal form of organization, and operational formats (from home, family owned, and initial employment as a measure of size) as further control variables. Given that business owners decide on some of these features (e.g., hours of work) after making the franchise decision, or these features can be part of the business format itself and thus jointly determined with the franchising decision, we should interpret the coefficients of these 
TABLE 4 Determinants of the franchise decision

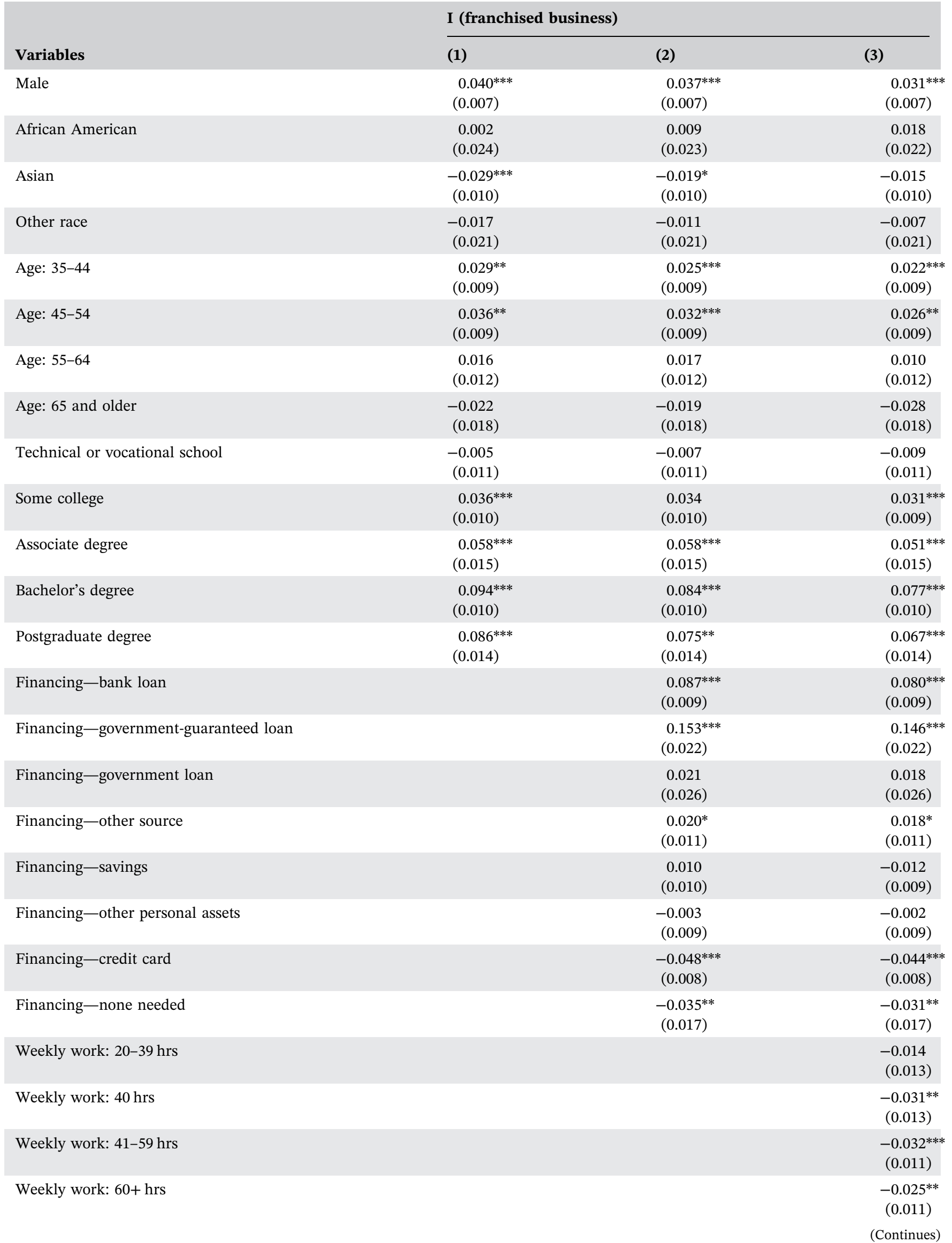


TABLE 4 (Continued)

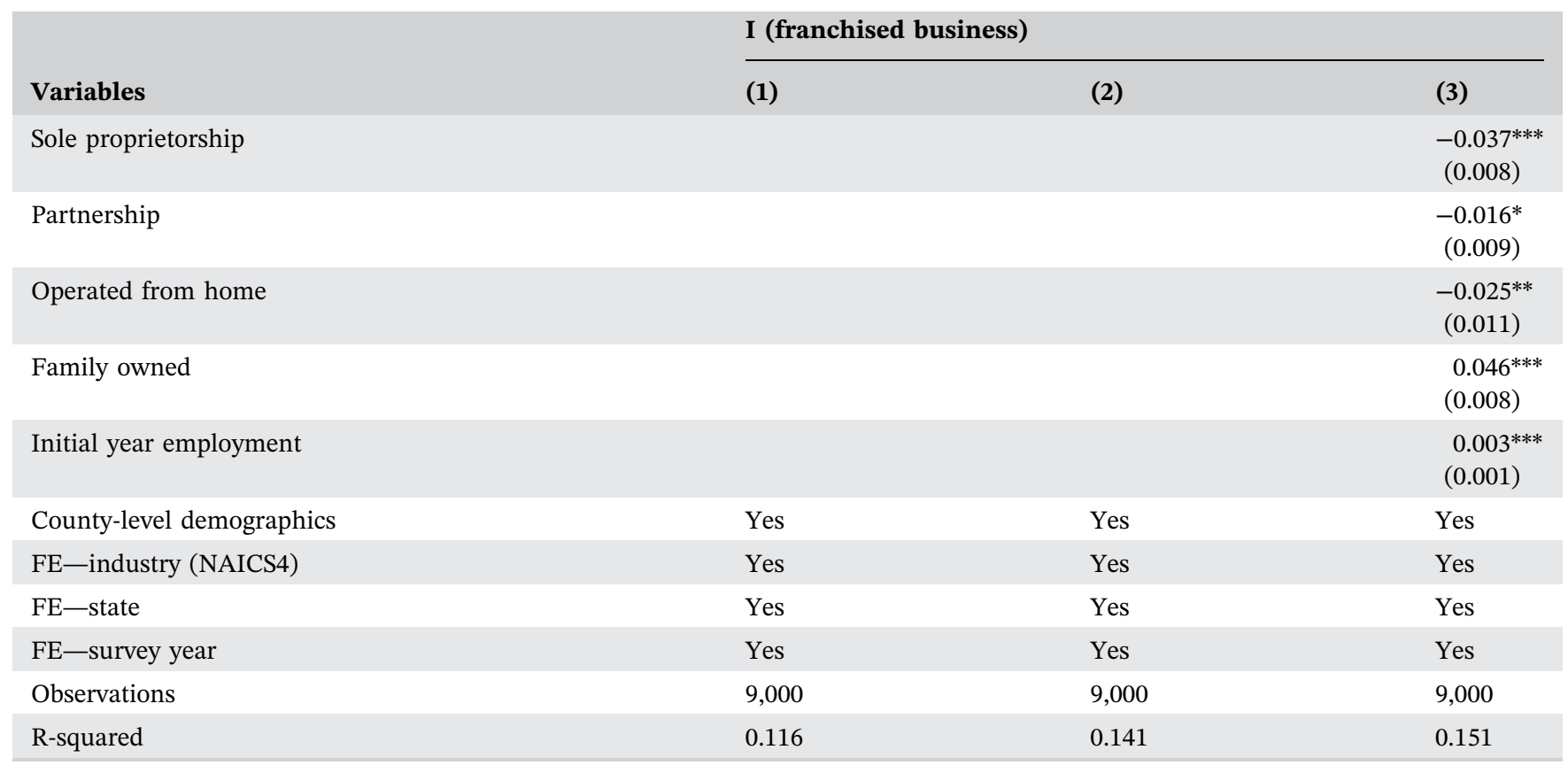

Note. Owner-level default categories are female, Caucasian, younger than 35 , and high school or less. ${ }^{* * *},{ }^{* *}$, and $*$ indicate statistical significance at the $1 \%, 5 \%$, and $10 \%$ levels, respectively. Robust standard errors are shown in parentheses. Market-level control variables are at the county level: (log) population, (log) average per capita income, percent male, percent Caucasian, percent African American, percent other race, Age: Percent 14 and younger, Percent 15-64, Percent 65 and older, percent at least high school degree, percent unemployed, (log) size of county in sq. miles, and indicator variables for whether the county is an MSA central county, an MSA outside county, or a non-MSA County. MSA: metropolitan statistical areas. FE: fixed effects

variables with caution. Still, it is interesting to find that franchising is correlated with lower work intensity, higher probability to be established as a corporation and to be family owned, and a lower likelihood of being operated from home.

Finally, although these coefficients are not shown in the table for space reasons, we control for local market characteristics in all the above regressions. We find that businesses in counties with more children and teenagers, and in central MSAs, are more likely to be franchised. However, overall, very few the local market demographics or characteristics have an effect that is statistically different from zero on the franchise decision.

\section{2 | Franchising survival and growth prospects}

\subsection{1 | Methods}

For our survival analyses, the dependent variable is an indicator variable for whether the business is still in operation $t$ years after it was established. We also examine the effect of franchising and other factors on conditional survival, that is, whether the business is still in operation at the end of year two (or three) conditional on having survived the first (or first two) year(s). When analyzing growth, the dependent variable is the employment growth rate, defined as (current year value minus previous year value)/previous year value. ${ }^{24}$ We estimate the following equation:

$$
Y_{i k c s t \tau}=f\left(\text { Franchise }_{i k c s}, X_{i k c s}, M_{\mathrm{ic}}, \eta_{k}, \delta_{s}, \gamma_{\tau}, \varepsilon_{i k c s t}\right)
$$

where, again, the subscript $i$ identifies a business started in an SBO survey year $\tau(2002,2007$, or 2012), $k$ indexes its sector (four-digit NAICS), $c$ denotes the county, and $s$ the state in which the business is located. The subscript $t$ on the dependent variable indicates the time frame over which we measure survival or growth.

We again use a linear probability model in these analyses, with dependent variables defined via indicator variables. This approach has several advantages relative to a duration model. First, with this approach, we can readily address the endogeneity or selection into franchising problem using propensity score matching, IVs, or a CF. Second, with a linear probability model, the analysis of survival, marginal survival, and growth are carried out 
under a single consistent framework, which facilitates the interpretation and comparisons of results throughout. Third, this approach allows us to clearly distinguish a potential one-time franchise advantage from an ongoing franchise advantage.

The main explanatory variable of interest in the regressions below is franchise. The $X$ and $\mathrm{M}$ vectors again represent the set of business owner, business, and market characteristics described above. In addition, we include sets of indicator variables for the business owner's decisions mentioned above, as these also could affect performance directly and thus bias the estimation of the effect of franchising on survival or growth. In particular, we control for the average number of hours worked in the business, the legal form of organization of the business, whether the business is operated primarily from home, and whether it is family owned. ${ }^{25}$ We also control for the size of the business at startup by including the initial year employment level. Finally, as in Table 4, we account for various common but unobserved factors within business survey year, and sectors and US states by including survey-year, industry (four-digit NAICS) and state fixed effects. Thus, essentially, the estimation exploits within survey year, within-industry and within-state variation in survival and growth between franchised and independent businesses, and controls for "selection into franchising" by including the many franchising decision determinants in Table 4.

Although the detailed business owner, business, and market characteristics should do a decent job of controlling for the "selection into franchising" problem, there could remain bias caused by potential unobserved characteristics in the error term. We therefore further explore the effect of the franchising decision on business survival and growth using other identification strategies, namely a propensity score matching approach, combined with Rosenbaum sensitivity tests, and both an IV and a CF approach. ${ }^{26}$

\subsection{2 $\quad$ Results}

In what follows, we satisfy the Census Bureau disclosure rules on sample sizes by showing and discussing results obtained for our combined SBO sample. In general, we obtained similar results using the yearly subsamples, except that the smaller sizes of the latter made the results statistically less robust.

\section{Baseline survival results}

The first three columns of Table 5 show results for the 1, 2, and 3-year survival rates of new single-establishment franchised and independent businesses using a linear probability model. Because the coefficients of the franchise indicator variable in these regressions are somewhat smaller, at 4.7, 6.0, and 6.4, respectively, than the mean differences of $6 \%, 7 \%$, and $9 \%$ shown in Table 2, we can conclude that there is evidence of "selection into franchising" in the data.

Beyond the effect of franchising, results in Table 5 also show that businesses of African American owners have lower survival rates, and businesses of Asian owners have higher survival rates, compared with Caucasian owners. Also, these gaps increase over time, as the survival rate differences are $-6.4 \%$ and $0.4 \%$ (and not statistically significant) in the first year for African American and Asian owners, respectively, whereas the 3-year survival rate differences are $-13.1 \%$ and $4.5 \%$, respectively. ${ }^{27}$

Turning to variables that are under the control of the business owner, not surprisingly, we find that working hard pays off. Businesses of owners who work at least $40 \mathrm{hrs}$ per week have about $7 \%$ higher chance of survival after 3 years compared with businesses of owners who work less than $20 \mathrm{hrs}$ per week. Of course, given that weekly working hours is a decision variable for the business owner, these results could mean that working hard really pays off through higher business survival rates, as per the interpretation above, or that owners put less effort into businesses that are not promising. Still, the observed correlation between effort and survival is worth noting. Similarly, businesses organized as corporations, the default category in our analyses, have substantially greater survival rates than those organized as proprietorships or partnerships. Also, larger-size new businesses and those financed by banks or government-backed loans tend to survive longer, whereas businesses operated from home and those financed using credit card debt have substantially lower survival probabilities. These results again might be capturing the effect of business owners' level of dedication to their ventures, rather than an effect of these characteristics, but the association of these characteristics with survival is nonetheless interesting.

In the last three columns of Table 5, we add interaction terms between the sources of financing and the franchise decision. We discuss these results further below, in Section "Explaining the sources of the short-term franchising advantage", where we consider the potential mechanisms explaining the franchise advantage. 
TABLE 5 The effect of franchising on business survival

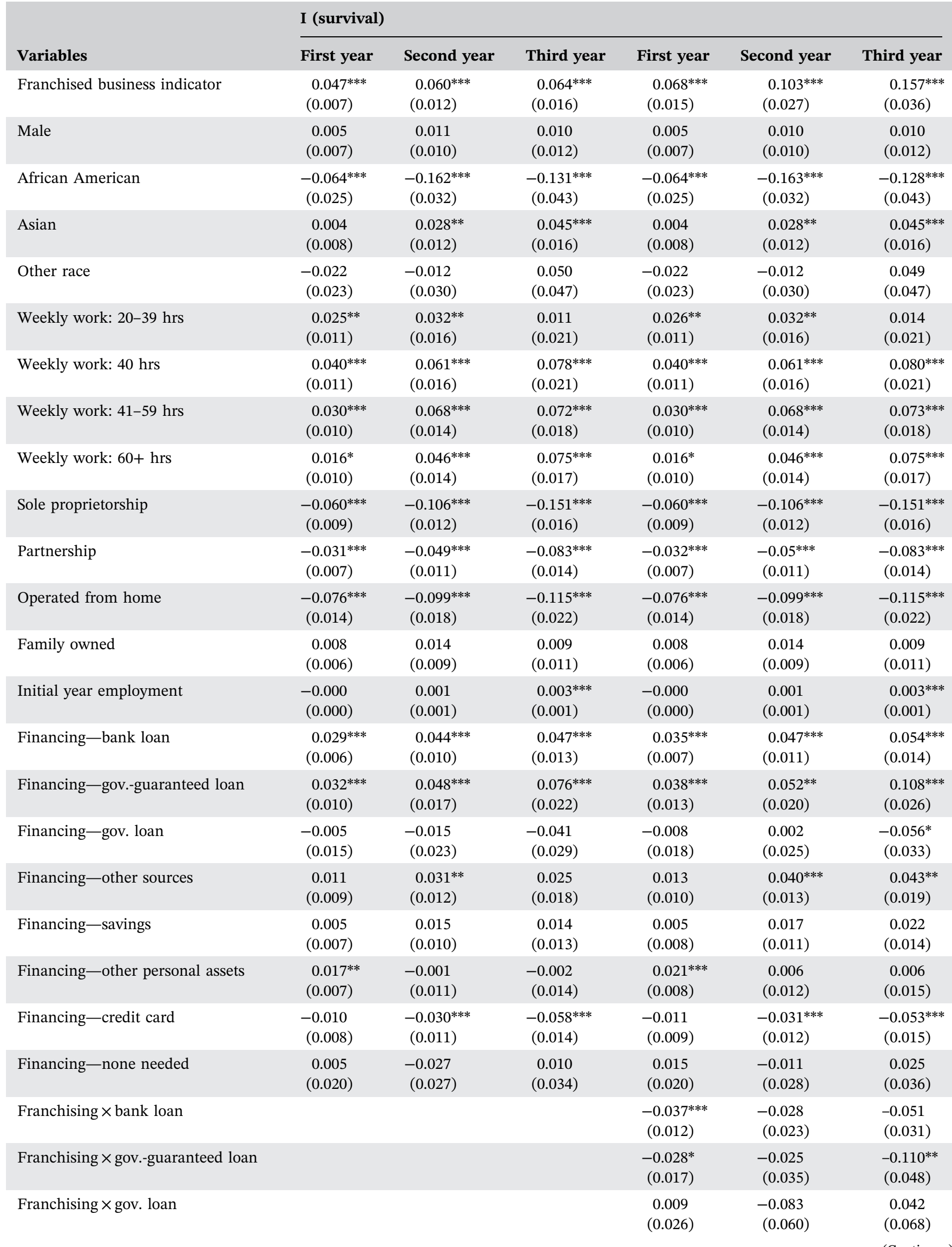


TABLE 5 (Continued)

\begin{tabular}{|c|c|c|c|c|c|c|}
\hline Variables & \multicolumn{6}{|l|}{ I (survival) } \\
\hline Franchising $\times$ other sources & & & & $\begin{array}{c}-0.021 \\
(0.017)\end{array}$ & $\begin{array}{c}-0.067^{* *} \\
(0.032)\end{array}$ & $\begin{array}{l}-0.118^{* *} \\
(0.046)\end{array}$ \\
\hline Franchising $\times$ savings & & & & $\begin{array}{c}0.008 \\
(0.014)\end{array}$ & $\begin{array}{c}-0.004 \\
(0.024)\end{array}$ & $\begin{array}{l}-0.033 \\
(0.032)\end{array}$ \\
\hline Franchising $\times$ credit card & & & & $\begin{array}{c}0.010 \\
(0.018)\end{array}$ & $\begin{array}{c}0.005 \\
(0.033)\end{array}$ & $\begin{array}{l}-0.060 \\
(0.045)\end{array}$ \\
\hline Franchising $\times$ none needed & & & & $\begin{array}{c}-0.154 \\
(0.104)\end{array}$ & $\begin{array}{c}-0.210^{*} \\
(0.123)\end{array}$ & $\begin{array}{l}-0.114 \\
(0.150)\end{array}$ \\
\hline FE-survey year & Yes & Yes & Yes & Yes & Yes & Yes \\
\hline Observations & 9,000 & 9,000 & 9,000 & 9,000 & 9,000 & 9,000 \\
\hline R-squared & 0.045 & 0.060 & 0.073 & 0.047 & 0.062 & 0.075 \\
\hline
\end{tabular}

Note. Owner age and education are also included, but their coefficients are not reported for brevity. ***, **, and * indicate statistical significance at the $1 \%, 5 \%$, and $10 \%$ levels, respectively. Robust standard errors are reported in parentheses.

\section{Marginal survival rates and growth}

We explore further the nature and extent of the franchising advantage by showing, in the first two columns of Table 6, the effect of franchising on marginal survival rates, that is, on the 2-year survival rate conditional on survival for 1 year and then on the 3-year survival rate conditional on survival for 2 years, using the same specifications as in Table 5. Results imply that the marginal survival advantage for franchised businesses is smaller-about $2.0 \%$ for the second year and not statistically significantly different from zero for the 3-year survival, conditional on survival for 2 years.

The second set of two columns in Table 6 show results for the establishment's employment growth. We see that from the first to the second year, franchised businesses expand quickly, growing $48 \%$ faster than do independent businesses in terms of employment. However, after the second year, the growth rates are not different between the two organizational forms, as neither type of business sees much employment growth at that point. In other words, employment for both franchised and independent businesses is basically unchanged from years two to three, as can be seen also in Table 2 .

TABLE 6 The effect of franchising on business marginal survival and growth

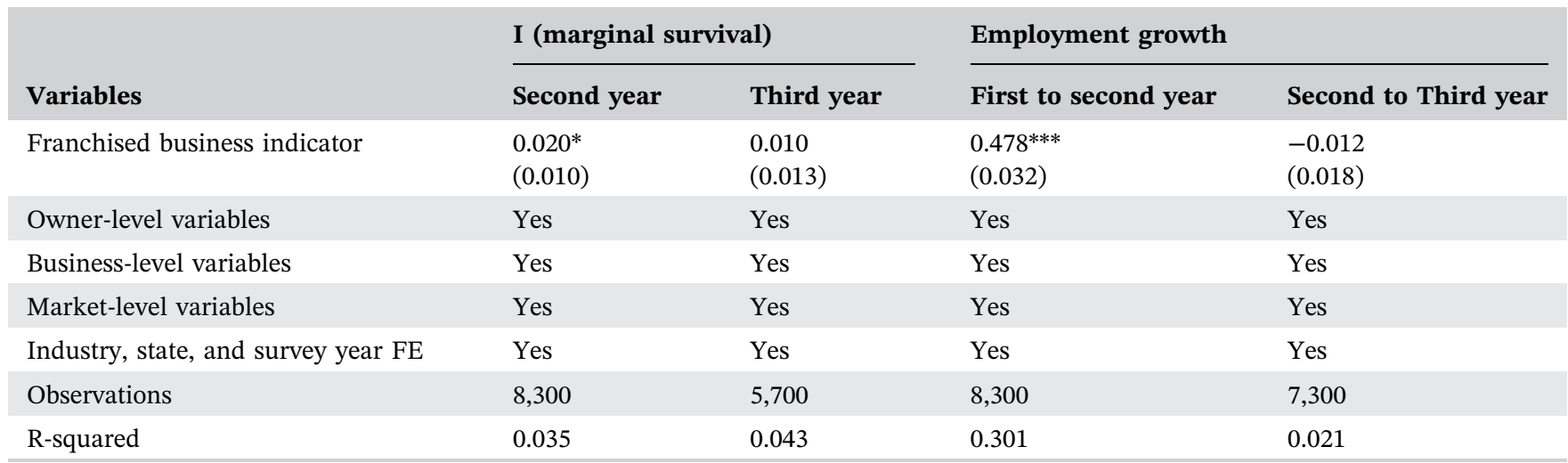

Note. ${ }^{* * *},{ }^{* *}$, and $*$ indicate statistical significance at the $1 \%, 5 \%$, and $10 \%$ levels, respectively. Robust standard errors are in parentheses. The sample is the 2002 , 2007, and 2012 combined sample in all columns except that as LBD 2015 is not available for the analysis, the sample in the second column is limited to the 2002 and 2007 combined sample. FE: fixed effects 


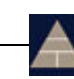

In sum, the noteworthy differences in survival in the summary statistics (Table 2) and the statistically significant results in Table 5 imply that franchised businesses indeed survive longer on average. This increased survival rate is a one-time persistent advantage: the 2-year and 3-year survival rates are also greater for franchised businesses. But conditional on having survived for a year, or for two, the difference in survival rates between franchised and independent businesses is much smaller, and conditional on surviving 2 years, not statistically distinguishable from zero. The same is true for employment growth: franchised businesses grow faster than independent businesses between their first and second year but not after.

One concern about the results in Tables 5 and 6 is that the coefficient of the franchising indicator variable may be biased due to some remaining unobserved factors that might affect both the franchising decision and survival or growth. We address this concern using propensity score matching with Rosenbaum sensitivity tests in the next subsection, and then with IV and CF approaches further below.

\section{Propensity score matching results}

Matching is a common nonparametric technique to evaluate binary treatments in the absence of a randomized controlled experiment. The basic idea is to match each treated subject with one or several untreated subjects with similar characteristics, and thereby form a "counterfactual" control outcome for the treated subject. With strong matching and an assumption that the treatment has been randomly assigned between the two matched observations, the difference between the realized outcome for the treated and the "counterfactual" is a consistent estimate for the treatment effect. Ideally, we would match each treated subject with a control subject with exactly the same characteristics on all the observables. However, this would give rise to the curse of dimensionality when a lot of covariates are present. Rosenbaum and Rubin (1983) propose matching based on a propensity score, which converts the relevant characteristics for matching to a single dimension.

Rosenbaum and Rubin's approach requires that we first estimate a probit model in which the outcome variable is an indicator variable equal to one if the business is franchised (i.e., treated) and zero otherwise. Because our goal is to match observations, the set of explanatory variables in this estimation contains all the variables presented in the last column of Table 4, including the market-level control variables. After estimating the propensity score, we use one-to-one no-replacement matching with a caliper radius of 0.25 on the common support of the treated and control groups. Then, we use balancing tests to assess whether the propensity score is such that, once we condition on the propensity score, the observables provide no further information about the treatment status.

There are two main advantages to this approach in addressing the "selection into franchising" problem. First, unlike our analyses in the previous subsection, this method does not impose a linearity assumption. Second, it allows us to directly add into our analyses a variable that we can use to test how much a "hidden" variable could affect our findings.

We report the results in Table 7, where the first three rows show the means for the treated and the matched control sample, and the difference between these two means. We report the standard error and the t-statistics for the difference in the next two rows. We find that the magnitudes of the estimated effects of franchising on survival rates, marginal survival rates, and employment growth rates are similar to those in Tables 5 and 6 , suggesting that the linearity assumption underlying the analyses in Tables 5 and 6 may be appropriate in this context.

The last two rows of Table 7 show results from the Rosenbaum bounds sensitivity tests (see Supporting Information Appendix A for details). These tests assess how likely it is that an unobserved determinant of the franchise decision could affect our conclusions regarding the effect of franchising on survival or growth. The critical cutoff values for Rosenbaum bounds (Rbounds) are defined as the highest value of the bound such that the measured treatment effect would still be statistically significant at the $5 \%$ level. To interpret the Rbounds cutoff values, we convert them into "maximum allowable deviations" in the last row of Table 7. Specifically, given that the average probability of starting a franchised business is $13.0 \%$, we calculate how large deviations an unobserved variable can maximally introduce on the probability of being franchised without undermining the statistically significant effect of franchising on survival or growth.

Results in Column 1 indicate that franchised businesses still would have a better chance of 1-year survival as long as the unobserved characteristic of the business or owner or local market that affects both the franchising decision and survival did not make the probability of starting a franchised business go outside the range of (8.1\% to $20.2 \%$ ). Compared with the mean probability of starting a franchised business of $13.0 \%$, this allowable deviation is quite large. In other words, the unobserved factor would have to have a substantial influence on the decision to franchise to alter our conclusion that the first-year survival of franchised businesses is greater than that of independent businesses. The ranges are smaller for the two- and three-year survival analyses, but the results in all three columns suggest the 
TABLE 7 The effect of franchising on business survival and growth, propensity score matching, and sensitivity tests

\begin{tabular}{|c|c|c|c|c|c|c|c|}
\hline \multirow[b]{2}{*}{ Variables } & \multicolumn{3}{|l|}{ I (survival) } & \multicolumn{2}{|c|}{ I (marginal survival) } & \multicolumn{2}{|c|}{ Employment growth } \\
\hline & $\begin{array}{l}\text { First } \\
\text { Year }\end{array}$ & $\begin{array}{l}\text { Second } \\
\text { Year }\end{array}$ & $\begin{array}{l}\text { Third } \\
\text { Year }\end{array}$ & $\begin{array}{l}\text { Second } \\
\text { Year }\end{array}$ & $\begin{array}{l}\text { Third } \\
\text { Year }\end{array}$ & $\begin{array}{l}\text { First to } \\
\text { Second Year }\end{array}$ & $\begin{array}{l}\text { Second to } \\
\text { Third Year }\end{array}$ \\
\hline Treated sample mean & 0.971 & 0.885 & 0.800 & 0.910 & 0.894 & 1.714 & 0.021 \\
\hline Control sample mean & 0.933 & 0.820 & 0.749 & 0.882 & 0.874 & 1.238 & 0.032 \\
\hline Difference & $0.039 * * *$ & $0.065^{* * *}$ & $0.051^{* * *}$ & $0.028^{* *}$ & 0.020 & $0.476^{* * *}$ & -0.022 \\
\hline t-stats & 4.32 & 4.34 & 2.60 & 2.13 & 1.25 & 10.27 & -0.94 \\
\hline $\begin{array}{l}\text { Rbounds critical } \\
\text { cutoff }(p=0.05)\end{array}$ & 1.7 & 1.3 & 1.2 & 1.1 & N/A & 1.8 & N/A \\
\hline $\begin{array}{l}\text { Maximum allowable } \\
\text { deviations }\end{array}$ & $(8.1 \%, 20.2 \%)$ & $(10.3 \%, 16.3 \%)$ & $(11.1 \%, 15.2 \%)$ & $(12.0 \%, 14.1 \%)$ & N/A & $(7.7 \%, 21.2 \%)$ & N/A \\
\hline
\end{tabular}

Note. ${ }^{* * *},{ }^{* *}$, and * indicate statistical significance at the $1 \%, 5 \%$, and $10 \%$ levels, respectively. Rbounds critical cutoff is defined as the highest value of the bound (referred to as $e^{\gamma}$ in Supporting Information Appendix A) such that the measured treatment effect is still statistically significant at the 5\% level. Maximum allowable deviations are the largest deviations that an unobserved variable could maximally introduce without undermining the statistically significant results given that the average probability of starting a franchised business is $13.0 \%$. The Rbounds critical cutoff values and the maximum allowable deviations are not available (N/A) if the original estimated results are statistically insignificant. As LBD 2015 is not available for the analysis, the sample used in the analysis involving the 3rd year survival and marginal survival includes only the 2002 and 2007 combined sample. SE: standard error.

differences in the data are quite robust to the potential existence of "hidden bias." Conditional on surviving a year or two, however, we again no longer find an effect of franchising on survival (or growth).

We conclude that the linear probability and propensity score matching results are quite consistent and that the franchise advantage we find constitutes a one-time benefit that allows franchised businesses to make it through their first year or two with somewhat greater probability, an advantage in the range of four to seven percentage points. However, once the business has been in operation for a year or two, there is no further contribution of franchising to its survival or growth. Given slightly larger first year employment levels in franchised business, the greater growth we observe between years one and two also implies that franchised establishments will be larger on average than nonfranchised establishments in the same industry. Our descriptive statistics in Table 2 confirm that this is the case on average in the data.

\section{Instrumental variable and control function approaches to identification}

In this section, we use both an IV and a CF approach to address the identification problem that is central to correctly assessing the effect of franchising on survival and growth (see Supporting Information Appendix B for implementation details). Because the CF approach is less robust than the IV approach, but more efficient if the model for the binary endogenous variable is correctly specified, we briefly discuss results from both approaches.

For both of these identification strategies, it is important to find variables that would affect the franchise decision, but not the performance (survival or growth) of the establishments. We make use of several such variables. In particular, for the first time, the 2007 Economic Census included questions on whether a business is franchised or not. We use these data to calculate the state-level proportion of franchised businesses in the same six-digit NAICS, and in related industries (all six-digit NAICS codes in the same two-digit NAICS code, excluding the one associated with the business in question). We believe that the proportion of establishments that are franchised in the focal or related industries will affect the franchise decision because they will be positively correlated with the availability and popularity of the franchising organizational form in the relevant industries and state, which in turn will affect the business owner's awareness of this option and the number of potential franchisors for his business. At the same time, these variables should not have a direct effect on the survival and growth of any particular establishment: Although the number of establishments in the same industry should affect business survival and growth because of competition, this should happen irrespective of whether the establishments are franchised or not. In other words, one would not expect the proportion of franchised businesses to affect the survival or growth of the focal business directly. The average franchise proportions in the relevant and related industries therefore meet the two properties needed (informative and exclusive) for a valid instrument. We also use the state-level proportion of company-owned establishments of franchised 
chains in the same industry (six-digit NAICS level) as another excluded (from the second stage) instrument. ${ }^{28}$ The argument for this instrument is as follows: because franchising is a joint decision, as franchised chains in an industry choose to own more establishments, fewer opportunities are available for potential entrepreneurs. Thus, the state-level proportion of company-owned establishments in the industry should have a negative effect on the franchising decision. There is no reason, however, for this proportion to have a direct effect on an individual business' survival or growth prospects. $^{29}$

The summary statistics for these IVs are provided in Table C1, and the first step regression results, in Table C2, both in Supporting Information Appendix C. The latter in particular confirms our expectation that greater reliance on franchising in the industry or in related industries has a positive effect, and the proportion of company-owned establishments of franchised chains in the industry has a negative effect, on the franchise decision.

We report results for new single-establishment business survival and growth using the IV and the CF approaches in Tables 8 and 9 respectively. Though the first stage results (see Supporting Information Appendix C, Table C3) suggest that our analyses do not suffer from the weak instrument problem, the estimated standard errors on the estimated coefficients are very large, such that basically none of the coefficients in Tables 8 and 9 are statistically significant. Results for employment growth from years one to two, however, continue to suggest sizable and significant positive effects of franchising.

The IV results suggest that after correcting for potential endogeneity, the estimated effect of franchising on business survival rates become smaller, possibly indicating that results about the franchise effect in Table 5 may be upward biased. The estimated coefficients on the generalized residual from the CF approach (Table 9) provide a possible explanation: Although generally not statistically different from zero, the coefficients on the generalized residual imply that potential unobserved factors that would be positively correlated with the franchise decision also have a positive effect on the survival rates, and a negative effect on the employment growth rate. One unobserved variable that could explain such relationships is the business owner's degree of risk aversion. If an entrepreneur is very risk averse, she may be more likely to start a franchised business, less likely to expand the business dramatically in the first year or two, and more likely to have garnered enough capital and to behave in such a way that the business is more likely to survive. In this case, results in Table 5, where we are not able to control for the business owner's risk aversion, would overestimate the survival benefit from franchising.

Although we believe that the results in Table 5 might somewhat overestimate the benefit from franchising, it is also clear that our IV and CF results are very noisy. This is not uncommon, and it suggests caution in interpreting the IV and $\mathrm{CF}$ results as well.

TABLE 8 The effect of franchising on business survival and growth, instrumental variable approach

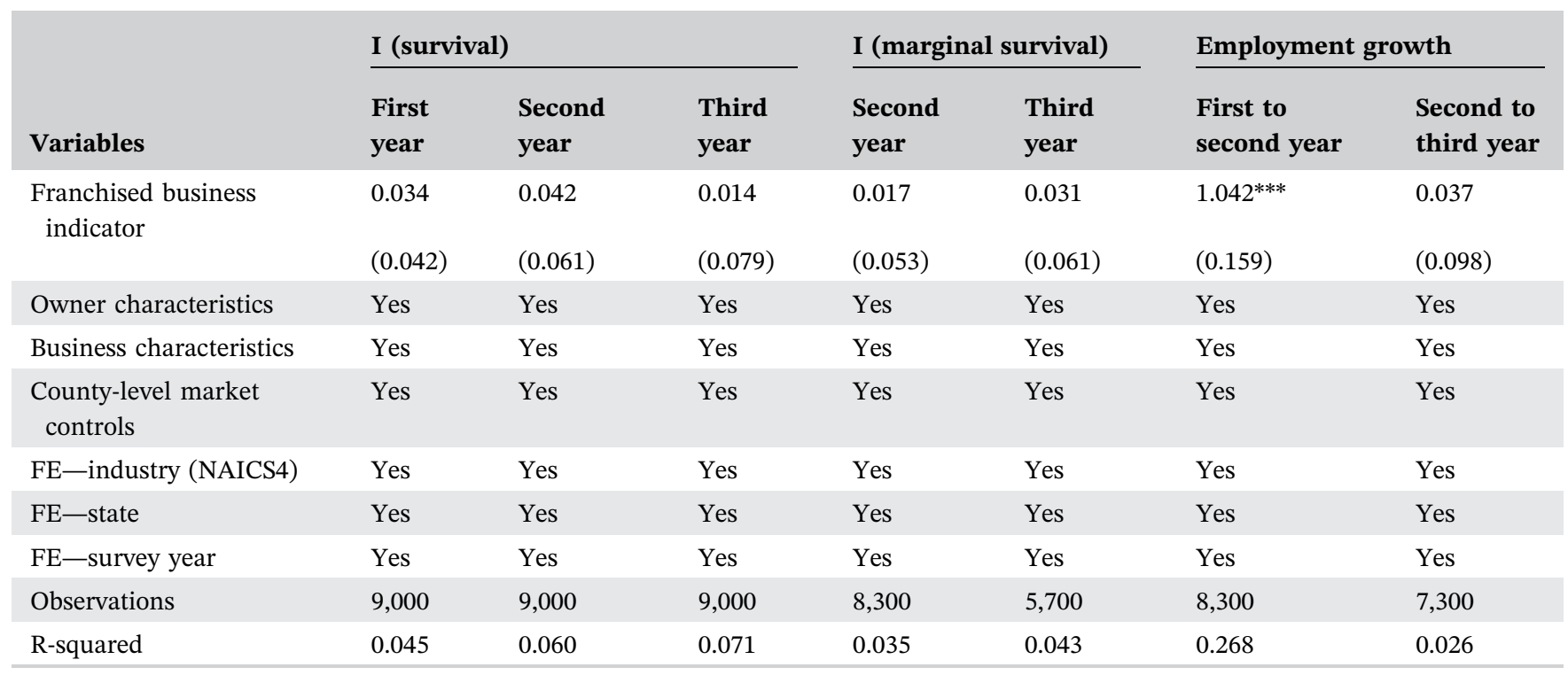

Note. ${ }^{* *},{ }^{* *}$, and $*$ indicate statistical significance at the $1 \%, 5 \%$, and $10 \%$ levels, respectively. Robust standard errors are in parentheses. FE: fixed effect 
TABLE 9 The effect of franchising on business survival and growth, control function approach

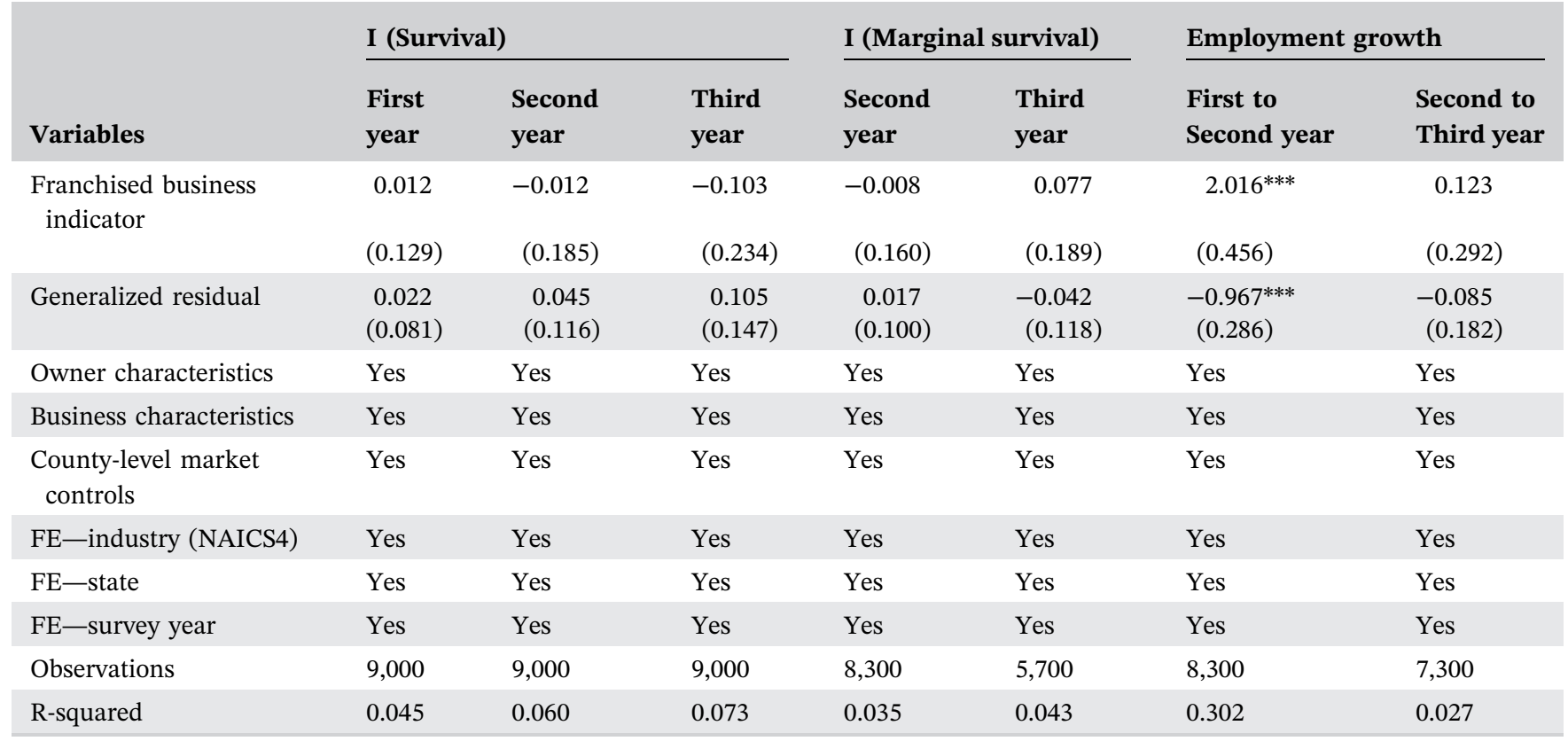

Note. ${ }^{* * *},{ }^{* *}$, and $*$ indicate statistical significance at the $1 \%, 5 \%$, and $10 \%$ levels, respectively. Robust standard errors are in parentheses. FE: fixed effects

We conclude from the preponderance of evidence that franchised businesses benefit from higher survival rates and faster growth initially relative to independent businesses, but that this effect is quite small and, conditional on surviving first year or two, franchised businesses no longer benefit from any enhanced survival or growth prospects.

\section{Explaining the sources of the short-term franchising advantage}

We have argued in Section 2 that there are two main potential sources of survival and growth advantages for franchised businesses: the literature mostly emphasizes the transfer of business know-how, supply network information, and brand recognition benefits, all of which are business-efficiency and demand enhancing benefits for franchised businesses. However, the increased performance could also arise from the franchisor's selection process.

To better understand the relative importance of these two potential sources of the small, short-term franchise advantage we find in the data, we explored various interaction effects. In the last three columns of Table 5, we present those we found most informative in this respect, namely results from adding interaction terms between the franchise indicator and sources of financing. ${ }^{30}$ Per the coefficient on "Financing-bank loan" in the last three columns of Table 5, financing via a bank loan is associated with 3.5, 4.7, and 5.4 percentage point increases in the 1, 2, and 3-year survival rates for independent businesses (the default category). But when the focal business is franchised, per the sum of the coefficients on "Financing—bank loan" and on "Franchising $\times$ bank loan," the effect of bank financing is small, and not statistically different from zero. We find a similar pattern of results for government-guaranteed loans. This suggests that franchisors, who screen their franchisees and business opportunities, leave little to no further room for banks and government agencies to play a role in the screening or selection process. It therefore appears that at least part of the short-term franchise advantage is associated with the selection process that franchisors, like banks and government agencies, engage in.

Next, we ask whether there is additional benefit from being a franchised business relative to the above selection benefit. To do so, we focus on businesses that have obtained a bank loan or a government-guaranteed loan, that is, businesses that have been screened by financial institutions. Within this set, the difference in survival rates between franchised and independent businesses provides an estimate of the franchising advantage that goes beyond the selection benefit. We find that conditional on getting a bank loan as a source of financing, franchised businesses still have a 3 to 10 percentage points higher survival rate than independent businesses in their first years in business. Similarly, conditional on getting a government-guaranteed loan, franchised businesses still have higher survival rates (4-8 percentage points higher) compared with independent businesses. ${ }^{31}$ These results suggest that, in addition to 
the selection benefits, franchised businesses obtain other benefits, which we expect arise from the business-enhancing benefits that the franchise literature points to when describing the benefits of franchising.

Our analyses thus confirm that both the selection process of the franchisor and the business know-how and brand benefits transferred from the franchisor are important sources for the short-term franchise advantage. Based on the magnitudes of the estimates, we conclude that the two sources contribute to a similar extent to the overall benefit we measure. $^{32}$

Finally, the fact that there is a lack of further franchise advantage survival or growth advantage beyond a year or two suggests two things regarding the sources of advantage described above. First, the market successfully screens the businesses of independent owners within the first year or two. Second, owners of independent businesses that survive a full year or so are able, within that time frame, to develop the needed expertise to compete successfully with franchised businesses. Of course, because franchisees must pay ongoing fees to obtain and maintain access to the expertise and resources provided by their franchisor, the long-term coexistence of both types of businesses in the marketplace is consistent with the conclusion that neither form dominates the other in a general sense, and thus with our finding that there is not an ongoing advantage of franchising once the firm has been in business for a year or two.

\section{5 | CONCLUSION}

The goal of this paper was to analyze whether franchising confers a survival and/or growth advantage to new businesses. We found first that in simple descriptive statistics, as well as in most of the specifications we used to address the issue of selection into franchising, there is a franchise advantage, but it is quite small relative to what is claimed in the trade press. We believe that the small size of the benefit likely reflects the fact that all new businesses, including independent businesses, have relatively high survival rates in our data. Second, conditional on surviving for a year or two, we found no further survival advantage for franchises. Similarly, we found some evidence that franchised businesses grow faster than independent businesses in the first two years, but no difference beyond that point.

We explored two mechanisms that could explain the observed small advantage we found. One of them is that franchisors expend resources to screen potential franchise owners and to select both market and business characteristics (location, market size, competition locally). They thereby prevent some potential owners, for example, those with more limited resources, from starting franchised businesses. Independent business owners are subjected to similar screening only if they are financed via outside sources, such as a bank loan or a government-guaranteed loan. Otherwise, the market plays this role during their first year in business, leading to more failures of independent businesses in the first year or two. The second potential mechanism is that franchisees benefit from the business knowledge and brand recognition obtained by being part of a franchised chain rather than being on their own. We find that both mechanisms are at play in the first year or two, and they are of similar importance as explanations for the franchise advantage. After the first year or two in business, the fees that franchisees pay on an ongoing basis for the services provided by their franchisors apparently lead to performance that is generally no better nor worse for franchised compared with independent businesses. This indeed seems consistent with the observation that both types of businesses continue to coexist in the marketplace.

Finally, our analyses also contribute to the literature on small business survival and growth. In particular, consistent with this literature, we found that some business owner characteristics, including race, age, and education, impact the survival probabilities of new businesses. Not surprisingly, we also found that the business owner's effort level, measured by the weekly number of hours worked, and the choice of legal form, namely the decision to incorporate the business rather than run it as a sole proprietorship or via a partnership, are both positively related to the business' survival and growth. Lastly, access to bank loans or government-guaranteed loans is strongly positively associated with survival and short-term growth. Of course, effort, legal form, and type of financing are determined endogenously, based on factors (such as the owner's resources and details of the business concept) that also directly affect survival and growth. As a result, while interesting, these relationships cannot be interpreted in a causal way.

\section{ACKNOWLEDGMENT}

Opinions and conclusions expressed herein are those of the authors and do not necessarily represent the views of the US Census Bureau or The Brattle Group. All results have been reviewed to ensure that no confidential information is disclosed. Support for this research at the Michigan Census Research Data Center is gratefully acknowledged. The 
authors thank participants at the Johns Hopkins Carey Business School economics seminar and 2018 Queen's University Organizational Economics Conference for their constructive comments.

\section{ENDNOTES}

${ }^{1}$ Source: https://factfinder.census.gov. Table "All Sectors: Core Business Statistics Series: Summary Statistics by Franchise Status for the United States: 2007." and the Economic Census report "Franchise Statistics: 2007” (Mesenbourg, 2010).

${ }^{2}$ See Blair and Lafontaine (2005), Chapter 2, for an overview of this literature.

3 The author attributes these high failure rates to the saturation and diminishing returns for newcomers in popular franchising niches.

${ }^{4}$ A related but separate literature considers factors that affect the decision to start a business. See notably Hurst and Lusardi (2004), Holtz-Eakin et al. (1994), Blanchflower and Oswald (1998), Kerr and Nanda (2011), and Franco (2005).

${ }^{5}$ NAICS stands for North American Industry Classification System, which is the standard industry classification used by US federal statistical agencies.

${ }^{6}$ For example, Daley (2013) mentions a Google search on franchise failure rates can lead to articles that claim extraordinarily high success rates for franchised businesses compared with independent businesses. The article goes on to mention that such statistics have fueled interest in franchising for decades, but they have no basis in reality.

${ }^{7}$ See for example Judd and Justis (1989) and Coughlan, Anderson, Stern and El-Ansary (2001) for such lists.

${ }^{8}$ See for example Jambulingam and Nevin (1999), Clarkin and Swavely (2006), and Gaul (2015) who point out that the key franchisee selection criteria include franchisees' financial resources, experience and management skills, demographic characteristics, and attitude toward the type of business. In the regression equation described at the beginning of Section 4.1, we include explanatory variables that capture some of the above key franchisee selection criteria, though our capacity to include these is limited by data availability. The inclusion of those variables suggests that our equation does not only consider the franchisee's decision but also reflects the franchisor's screening process to some extent. See also Nathan (2017) for a practice-oriented discussion of best practices for franchisee selection.

${ }^{9} \mathrm{http} / / /$ www.bluemaumau.org/sba_franchisee_failure_rates_brand_2012.

${ }^{10} \mathrm{http} / / /$ www.bluemaumau.org/sba_loan_failure_rates_industry_20002009.

11 The Characteristics of Business Owners (CBO) database used by Bates (1995a), (1995b), and (1998) and Williams (1999) was the precursor of the SBO. However, the CBO sample was much smaller.

12 More information about the LBD can be found in Jarmin and Miranda (2002).

13 This condition does not rule out the possibility that an owner might have had a prior business that has been closed by the time they open the new business. However, the proportion of new business owners who have owned a previous employer business is small. Per the 2012 SBO, from factfinder.census.gov, $35.7 \%$ of owners opening a new business have previously owned another business or were self-employed. Among these, the ratio of those owning a prior employer business to those who are self-employed is 80:20. Thus, on average, only around 7\% (one fifth of 35.7\%) of business owners have previously owned an employer business. By definition, the proportion of those who have had such a business but closed it before opening the new business featured in our data is necessarily smaller still. Moreover, while unavailable for the 2002 data, and thus for our baseline analyses, we can add an indicator variable for prior experience when people have answered "Yes" to the question, posed in the 2007 and 2012 SBO: "Before establishing, purchasing, or acquiring this business, had the owner ever owned a business or been self-employed?" We find that the coefficient for this indicator variable in our survival regressions is very small, less than 0.01 , and that it is statistically insignificant. This gives us confidence that focusing on single-establishment businesses controls for most of the impact of prior business experience on business performance.

14 The concern is that the proportion of franchised relative to independent businesses that survive for any period of time may differ, such that conclusions based on subsets of businesses that have survived up to the survey year could bias our main coefficients of interest.

${ }^{15}$ See Kosová and Lafontaine (2012), Table 2, for the data needed to calculate this proportion.

${ }^{16}$ See the Appendix for a detailed description of the data and how we arrive at our final sample. Due to Census disclosure rules, all counts are rounded: if $N$ is less than 100, we round to the nearest 10 ; if $N$ is between 100 and 999 , we round to the nearest 50 ; if $N$ is between 1,000 and 9,999 , we round to the nearest 100. We use these rules throughout the paper, unless noted otherwise.

17 The main concern of this Census coding practice arises only if one expects new successful franchisees to be more likely than new successful independent business owners to sell their business within their first few years in operation to pursue other opportunities. In this case, the difference in survival rates and the coefficient on the franchise status in our survival regressions, would be biased downwards. However, we have no reason to expect, nor any data to suggest, that the tendency of new owners to sell their business within their first few years for such reasons is greater for franchisees than for independent business owners.

${ }^{18}$ See Table D1 in Supporting Information Appendix D for descriptive statistics for the yearly SBO samples.

19 Employment numbers in the first year may be small for two potential reasons. First, businesses often start relatively small. Second, if a business starts in the middle of a year, the number of employees as captured in the LBD on a single date in March would underestimate the full year level of employment. Because the issue of the small employment numbers in the first year affects both franchised and independent businesses in similar ways, the results comparing the effect of the two business formats on business growth rates should be valid.

${ }^{20}$ The sample selection steps described in the appendix likely contribute to the difference in average survival rates between our data and the more comprehensive LBD sample. In particular, excluding observations with imputed and missing values likely leads to the higher survival rates of the businesses in our sample.

${ }^{21}$ Because we believe it is unlikely that franchisor characteristics affect any of the variables included on the right-hand side of our franchising decision regression, estimates from this regression should be consistent.

${ }^{22}$ See the Supporting Information Appendix D, Table D2, for linear probability results for each SBO year. 
${ }^{23}$ Note that government-guaranteed loans are different from government loans. In the former case, the government does not provide a loan but instead provides guarantees to banks or financial institutions, thereby protecting them against defaults. SBA-guaranteed loans are a type of government-guaranteed business loan.

${ }^{24}$ We performed all the growth analyses using both growth in employment and growth in payroll. As the results from the two measures were similar, we only report findings from the employment growth regressions.

${ }^{25}$ The family owned variable is coded based on a question that asks whether the majority of the business is owned by members of the same family.

${ }^{26}$ For more details, see Supporting Information Appendices A and B.

27 Though not reported in the table, we also find that business owners in the 45-54 age group perform best, with a 3\% higher 3-year survival rate compared with those who are under 35 years old. We also find that compared with businesses started by people who have a high school education level or less, those started by people who have a technical or vocational education or a bachelor's degree have greater survival rates. However, businesses of owners with some college or a college degree, or an associate degree, or a postgraduate degree, have no greater survival rates than businesses of owners who have less than or equal to a high school education level.

${ }^{28}$ If a six-digit NAICS level measure is unavailable because of too few observations, when the number of observations is less than 10, we use the four-digit NAICS level instead. Specifically, we calculate the state-level proportion of businesses of franchised chains in the same industry (four-digit NAICS level) and in related industries (different four-digit but same two-digit NAICS code), and the state-level proportion of company-owned establishments among establishments of franchised chains in the same four-digit NAICS industry to impute values for these variables when the six-digit NAICS level measures are missing.

${ }^{29}$ One may argue about the validity of this instrument if company-owned establishments are better run, and thus can compete more effectively, such that more of them in a market would lead to greater competition locally. But that should mean that all businesses in this local market are facing increased competition, and so the survival and growth of franchised and independent businesses, once we control for state and industry fixed effects, should be affected similarly. Thus, this instrument is still valid and the franchise "advantage" would still be identified.

${ }^{30}$ In addition to including interaction terms between the franchise indicator and sources of financing, we also explored interaction terms between the franchise indicator and legal forms of organization. Results for these specifications are available in Supporting Information Appendix D, Table D3. We find that corporations perform better than partnerships which perform better than sole proprietorships for independent businesses, but there is no statistically significant difference among these three for franchised businesses. In addition, we examined the interaction terms between the franchise indicator and education levels as well as the interaction terms between the franchise indicator and work intensity, but we find the education effects and the work intensity effects are similar between franchised and independent businesses.

${ }^{31}$ This effect is measured by the survival difference between franchised businesses and independent businesses conditional on getting a bank loan. Essentially, it is the sum of the coefficients on the franchise indicator variable and the Franchising $\times$ bank loan indicator variable (e.g., in Column 4 , 6.8$3.7 \%=3.1 \%$ for the first year).

32 As described earlier, after the screening process by franchisors, there is little room for banks and government agencies to play a role in the screening or selection process. Thus, the benefit from selection can be approximately measured by the coefficient on the Financing-bank loan indicator variable or the Financing-government-guaranteed loan indicator variable. These are 3.5, 4.7, and 5.4 percentage points based on the former, and 3.8, 5.2, and 10.8 based on the latter. As mentioned in the body of this paper, the remaining effect of franchising conditional on a bank loan is calculated at 3.1, 7.5, and 10.6 percentage points, whereas with government-backed loans, the results leave 4.0, 7.8, and 4.7 percentage points as measures of the nonselection effect of franchising. As these estimates are generally similar, we conclude that the selection and the business-enhancing effects of franchising are of similar magnitudes.

\section{ORCID}

Francine Lafontaine (D) http://orcid.org/0000-0001-5268-5097

Marek Zapletal (1) http://orcid.org/0000-0002-1218-608X

Xu Zhang (1) http://orcid.org/0000-0002-7640-0225

\section{REFERENCES}

Agarwal, R., \& Audretsch, D. B. (2001). Does entry size matter? The Impact of the life cycle and technology on firm survival. Journal of Industrial Economics, 49(1), 21-43.

Audretsch, D. B., Houweling, P., \& Thurik, A. R. (2000). Firm survival in the Netherlands. Review of Industrial Organization, 16(1), 1-11. Audretsch, D. B., \& Mahmood, T. (1995). New firm survival: New results using a hazard function. Review of Economics and Statistics, 77(1), 97-103.

Bates, T. (1990). Entrepreneur human capital inputs and small business longevity. Review of Economics and Statistics, $72(4), 551$.

Bates, T. (1995a). Analysis of survival rates among franchise and independent small business startups. Journal of Small Business Management, 33(2), 26-36.

Bates, T. (1995b). A comparison of franchise and independent small business survival rates. Small Business Economics, 7(5), $377-388$.

Bates, T. (1998). Survival patterns among newcomers to franchising. Journal of Business Venturing, 13(2), 113-130.

Blair, R. D., \& Lafontaine, F. (2005). The Economics of Franchising. Cambridge, UK: Cambridge University Press.

Blanchflower, D. G., \& Oswald, A. J. (1998). What makes an entrepreneur? Journal of Labor Economics, 16(1), 26-60. 
Boden, R. J., \& Nucci, A. R. (2000). On the survival prospects of men's and women's new business ventures. Journal of Business Venturing, 15 (4), 347-362.

Carpenter, R. E., \& Petersen, B. C. (2002). Is the growth of small firms constrained by internal finance? Review of Economics and Statistics, 84 (2), 298-309.

Clarkin, J. E., \& Swavely, S. M. (2006). The importance of personal characteristics in franchisee selection. Journal of Retailing and Consumer Services, 13(2), 133-142.

Cooper, A. C., Gimeno-Gascon, F. J., \& Woo, C. Y. (1994). Initial human and financial capital as predictors of new venture performance. Journal of Business Venturing, 9(5), 371-395.

Coughlan, A., Anderson, E., Stern, L. W., \& El-Ansary, A. (2001). Marketing channels (6th ed.). Upper Saddle River, NJ: Prentice Hall.

Cressy, R. (1996). Are business startups debt-rationed? Economic Journal, 106(438), 1253.

Daley, J. (2013, August). What is the real survival rate of franchised businesses? Entrepreneur. Retrieved from https://www.entrepreneur. com/article/227394, accessed on January 11, 2018.

Evans, D. S., \& Leighton, L. S. (1989). Some empirical aspects of entrepreneurship. American Economic Review, 79(3), 519-535.

Fairlie, R. W., \& Robb, A. M. (2008). Race and Entrepreneurial Success. Cambridge, MA: The MIT Press.

Fan, Y., Kühn, K. U., \& Lafontaine, F. (2017). Financial constraints and moral hazard: The case of franchising. Journal of Political Economy, 125(6), 2082-2125.

Franco, A. (2005). Employee entrepreneurship: recent research and future directions, Handbook of Entrepreneurship Research (81-86). Springer US.

Fritsch, M., Brixy, U., \& Falck, O. (2006). The effect of industry, region, and time on new business survival-A multi-dimensional analysis. Review of Industrial Organization, 28(3), 285-306.

Gaul, C. (2015). What makes a franchisee successful: Attitudes and pre-requisites of profitable franchise partners. International Business and Economics Research Journal, 14(2), 387-394.

Haapanen, M., \& Tervo, H. (2009). Self-employment duration in urban and rural locations. Applied Economics, 41(19), $2449-2461$.

Holtz-Eakin, D., Joulfaian, D., \& Rosen, H. S. (1994). Sticking it out: Entrepreneurial survival and liquidity constraints. Journal of Political Economy, 102(1), 53-75.

Hurst, E., \& Lusardi, A. (2004). Liquidity constraints, household wealth, and entrepreneurship. Journal of Political Economy, 112 (2), $319-347$.

Jambulingam, T., \& Nevin, J. R. (1999). Influence of franchisee selection criteria on outcomes desired by the franchisor. Journal of Business Venturing, 14(4), 363-395.

Jarmin, R. S. and Miranda, J. (2002). The longitudinal business database, Center for Economic Studies Discussion Paper CES-WP-02-17.

Judd, R. J., \& Justis, R. T. (1989). Franchising. Cincinnati, OH: South-Western Publishing.

Kalleberg, A. L., \& Leicht, K. T. (1991). Gender and organizational performance-Determinants of small business survival and success. Academy of Management Journal, 34(1), 136-161.

Kalnins, A., \& Lafontaine, F. (2013). Too far away? The effect of distance to headquarters on business establishment performance. American Economic Journal: Microeconomics, 5(3), 157-179.

Kalnins, A., \& Mayer, K. J. (2004). Franchising, ownership, and experience: A study of pizza restaurant survival. Management Science, 50(12), 1716-1728.

Kamshad, K. M. (1994). Firm growth and survival: Does ownership structure matter? Journal of Economics and Management Strategy, 3(3), 521-543.

Kaufmann, P. J. (1999). Franchising and the choice of self-employment. Journal of Business Venturing, 14(4), $345-362$.

Kerr, S., Kerr, W. R., and Nanda, R. (2015) House money and entrepreneurship (Working Paper, No. 15-069). Boston, MA: Harvard Business School.

Kerr, W. R., \& Nanda, R. (2011). Financing constraints and entrepreneurship, Handbook of Research on Innovation and Entrepreneurship. Edward Elgar Publishing

Kosová, R., \& Lafontaine, F. (2012). Much ado about chains: A research agenda. International Journal of Industrial Organization, 30, 303-308.

Kosová, R., Lafontaine, F., \& Perrigot, R. (2013). Organizational form and performance: Evidence from the hotel industry. Review of Economics and Statistics, 95(4), 1303-1323.

Lafontaine, F., \& Shaw, K. (2016). Serial entrepreneurship: Learning by doing? Journal of Labor Economics, 34(S2), $217-253$.

Lazear, E. P. (2004). Balanced skills and entrepreneurship. The American Economic Review, 94(2), 208-211.

Mazzeo, M. J. (2004). Retail contracting and organizational form: Alternatives to chain affiliation in the motel industry. Journal of Economics and Management Strategy, 13(4), 599-615.

Mesenbourg, T. L. (2010). Franchise Statistics: 2007. The Economic Census Report, Suitland, MD: U.S. Census Bureau.

Millán, J. M., Congregado, E., \& Román, C. (2010). Determinants of self-employment survival in Europe. Small Business Economics, 38(2), 231-258.

Nathan, G. (2017). Best Practice in Franchisee Selection. http://www.franchiserelationships.com/articles/BestPracticesinFranchiseeEvaluation. html, accessed on January 11, 2018.

Pfeiffer, F., \& Reize, F. (2000). Business start-ups by the unemployed-An econometric analysis based on firm data. Labour Economics, 7(5), 629-663. 
Rosenbaum, P. R., \& Rubin, D. B. (1983). The central role of the propensity score in observational studies for causal effects. Biometrika, 70(1), 41-55.

Schäfer, D., \& Talavera, O. (2007). Small business survival and inheritance: Evidence from Germany. Small Business Economics, 32(1), 95-109.

Stanworth, J., Purdy, D., Price, S., \& Zafiris, N. (1998). Franchise versus conventional small business failure rates in the US and UK: More similarities than differences. International Small Business Journal: Researching Entrepreneurship, 16(3), 56-69.

Tveterås, R., \& Eide, G. E. (2000). Survival of new plants in different industry environments in norwegian manufacturing: AS semiproportional cox model approach. Small Business Economics, 14(1), 65-82.

Wagner, J. (1994). The post-entry performance of new small firms in german manufacturing Industries. Journal of Industrial Economics, 42 (2), 141-154.

Williams, D. L. (1999). Why do entrepreneurs become franchisees? An empirical analysis of organizational choice. Journal of Business Venturing, 14(1), 103-124.

\section{SUPPORTING INFORMATION}

Additional supporting information may be found online in the Supporting Information section at the end of the article.

How to cite this article: Lafontaine F, Zapletal M, Zhang X. Brighter prospects? Assessing the franchise advantage using census data. J Econ Manage Strat. 2019;28:175-197. https://doi.org/10.1111/jems.12289 